NBER WORKING PAPER SERIES

\title{
KEEP IT SIMPLE: A FIELD EXPERIMENT ON INFORMATION SHARING IN SOCIAL NETWORKS
}

\author{
Cátia Batista \\ Marcel Fafchamps \\ Pedro C. Vicente \\ Working Paper 24908 \\ http://www.nber.org/papers/w24908 \\ NATIONAL BUREAU OF ECONOMIC RESEARCH \\ 1050 Massachusetts Avenue \\ Cambridge, MA 02138 \\ August 2018
}

We benefited from comments from Yves Zenou, Sanjeev Goyal, Francis Bloch, Markus Goldstein, and participants to the Monash University Conference on Social Networks 2018. We wish to thank Stefan Leeffers, Timoteo Simone, and the NOVAFRICA office in Mozambique for excellent research assistance. We are particularly grateful to Carteira Movel/Mkesh for institutional support. We wish to acknowledge financial support from the International Growth Centre. IRB approval was secured with Universidade Nova de Lisboa. None of the authors has financial or institutional affiliation with Carteira Movel/Mkesh. All errors are our responsibility. The views expressed herein are those of the authors and do not necessarily reflect the views of the National Bureau of Economic Research.

NBER working papers are circulated for discussion and comment purposes. They have not been peer-reviewed or been subject to the review by the NBER Board of Directors that accompanies official NBER publications.

(C) 2018 by Cátia Batista, Marcel Fafchamps, and Pedro C. Vicente. All rights reserved. Short sections of text, not to exceed two paragraphs, may be quoted without explicit permission provided that full credit, including $(\odot$ notice, is given to the source. 
Keep It Simple: A Field Experiment on Information Sharing in Social Networks

Cátia Batista, Marcel Fafchamps, and Pedro C. Vicente

NBER Working Paper No. 24908

August 2018

JEL No. D64,D83,O33

\begin{abstract}
$\underline{\text { ABSTRACT }}$
SMS information campaigns are increasingly used for policy. To investigate their effectiveness, we conduct a lab-in-the-field experiment to study information sharing through mobile phone messages. Subjects are rural households in Mozambique who have access to mobile money. In the base treatment, subjects receive an SMS containing information on how to redeem a voucher. They can share this information with other exogeneously assigned subjects. We find that few participants redeem the voucher. They nonetheless share it with others and many share information they do not use themselves. Information is shared more when communication is anonymous and we find no evidence of homophily in information sharing. We introduce treatments to vary the cost of sending a message, shame those who do not send the voucher to others, or allow subjects to appropriate the value of information. All decrease information sharing. To encourage information sharing, the best is to keep it simple.

Cátia Batista

Nova School of Business and Economics

Universidade Nova de Lisboa

Campus de Carcavelos

Rua da Holanda, 1

2775-405 Carcavelos

Portugal

catia.batista@novasbe.pt

Marcel Fafchamps

Freeman Spogli Institute

Stanford University

616 Serra Street

Stanford, CA 94305

and NBER

fafchamp@stanford.edu

Pedro C. Vicente

Nova School of Business and Economics

Universidade Nova de Lisboa

Campus de Carcavelos

Rua da Holanda, 1

2775-405 Carcavelos

Portugal

pedro.vicente@novasbe.pt
\end{abstract}


The sharing of valuable information is at the heart of many important economic processes: the diffusion of new technology (e.g., Ryan and Gross, 1943; Griliches, 1957; Foster and Rosenzweig, 1995; Bandiera and Rasul, 2006; Beaman ,Ben Yishay, Magruder, and Mobaraq, 2015; Carter, Laajaj, and Yang, 2016); the adoption of new consumer products (e.g., Fafchamps, Soderbom and vanden Boogaart, 2017); credit reference services (e.g., Kandori, 1992; Greif, 1993); information about market opportunities (e.g., Granovetter, 1974; Fafchamps and Minten, 2012); and the referral of workers and trainees (e.g., Beaman and Magruder, 2012; Fafchamps, Islam, Malek, and Pakrashi, 2017). Information sharing is also essential to social learning, i.e., the process by which crowds form inference by aggregating dispersed information (e.g., Golub and Jackson, 2010).

Two assumptions are implicit in much of this work. First, it is assumed that people are not willing to share information when doing so brings no immediate or delayed benefit. In effect, even when the information itself is non-rival, sharing typically imposes a cost on the sender. Secondly, the recipient must put some trust in the information provided even though, in many cases, the quality of the information cannot be verified, or can only be verified at a cost. These two phenomena introduce friction: some valuable information is not shared, and some of the shared information is not believed.

Epidemiological models of diffusion on networks (e.g., see the excellent reviews by VegaRedondo, 2007, and Jackson, 2010) have demonstrated that small changes in the probability that a message is successfully transferred between two nodes can have dramatic effects on the spread of information. For instance, in Poisson random networks with $n$ nodes, a giant component emerges when the link probability $p$ rises above $\frac{1}{n}$ and it grows in size until $p$ reaches $\frac{\log (n)}{n}$, at which point the network becomes fully connected. This means that if $p$ represents the probability with which information is successfully transferred between two arbitrary nodes in a large network, when $p<\frac{1}{n}$ only a vanishingly small proportion of nodes will be informed, while if $p>\frac{\log (n)}{n}$, all nodes will be informed. It follows that small frictions in information sharing can have large consequences on information spread and thus on efficiency.

Given this, it is somewhat surprising that little empirical research has sought to ascertain the extent to which individuals successfully share valuable information with each other. We know very little about whether recipients actually read or believe the messages they receive, and whether they forward these messages to others. The purpose of this paper is to investigate this formally using an original field experiment implemented through text messages on mobile phones.

In our base game, selected volunteers receive an SMS voucher that they can redeem for mobile money. The voucher SMS is intended to represent a generic piece of valuable information. By taking valuable information to be on how to receive a monetary transfer, we eschew the possibility that a piece of information may have a different value for different subjects. Having received the SMS, subjects can make the same voucher opportunity available to up to four other subjects who, in turn, can redeem it for cash and pass it on to others. This information transfer process goes on for several rounds. We focus our attention on whether people redeem the voucher and 
whether they pass it on to others. This experimental design mimics, in a stylized fashion, the process by which people share information with others by passing on or re-posting messages that they have received. From redeeming behavior we measure the extent to which messages are read and believed. From sending behavior we measure the willingness to share valuable information.

We study a network of rural individuals (heads of households or their spouses) in Mozambique. This network links individuals that were not connected before our study. Importantly, links are randomly selected, making this network an exogenous one. All communication is conducted through text messages that transit through the experimenter's switchboard. These features severely limit the possibility of unobserved communication outside the experiment. Since the vouchers that can be shared and redeemed are for mobile money, we had to ensure familiarity with this form of money: we recruit all the participants among individuals who were previously introduced to mobile money services, used the services, and have mobile money accounts on their mobile phones.

We find that a surprisingly small proportion of recipients redeem the voucher: 26 percent in the base game, and even fewer in most other treatments. This is a surprising result given that redeeming the voucher is a low cost, high return action. This suggests that many subjects either ignore the messages they receive, or do not trust them. At the same time, we find that subjects often share the voucher message with others, even when they do not redeem it themselves. In other words, some people incur a cost to share information that they do not themselves believe. This type of behavior is more consistent with a warm glow motivation (e.g., Andreoni, 1990) than with pure altruism. ${ }^{1}$ As a result of limited sharing, information about the redeemable voucher fails to spread - i.e., $p$ is below $1 / n$.

To investigate factors that affect the circulation of valuable information among subjects, we introduce treatments that affect the way that information is shared. More precisely, we vary: the extent of anonymity in both redeeming and sending decisions; the costs of sending vouchers; and the inclusion of alternatives to sending vouchers. We also implement versions of the dictator, ultimatum, and reverse dictator games adapted to our design. At the same time, we undertake this testing in a real-world setting relevant for development policy: that of a widespread communication platform, i.e., phone-based written communication, and of a recently introduced money transfer technology, i.e., mobile money.

We find that disclosing key characteristics of the sender or recipient reduce information sharing: both redeeming and sending fall. This pattern reveals higher levels of trust when subjects are uninformed about the specific characteristics of the sender or recipient. We do not observe an effect of varying the cost of sending the voucher, but information sharing falls once any explicit monetary cost is introduced. The peer characteristics visible to decision-makers do not impact either redeeming or sending vouchers. We find no evidence that the possibility of shaming increases information sharing. In one treatment, we introduce the ability to circulate erroneous information. We find little take-up, suggesting that most subjects do not purposefully

\footnotetext{
${ }^{1}$ By definition an altruist cares about the utility of others, not just about the action of giving. An altruist who believes that paying to redeem the voucher is not beneficial would presumably not want to share it with others.
} 
set out to harm others by sending false information. We find no evidence that allowing senders to extract or solicit payment increases information circulation.

This paper contributes to the literature in several ways. First it complements a theoretical literature on diffusion that takes information transfer in human populations as a given (e.g., Kandori, 1992; Greif, 1993; Bloch, Genicot, and Ray 2008; Jackson, Rodriguez-Barraquer, and Tan, 2012). Our results cast some doubts on the implementability of strategic mechanisms that rely on the near perfect sharing of non-rival information. Second, our work generalizes earlier findings by Mobius, Phan, and Szeidl (2015) who examine how people share and aggregate information that helps them win movie tickets. Like us, they find that diffusion is highly imperfect: signals travel only up to two network steps. It is however unclear how general their findings are, due to the strategic complexity of their design and the fact that information is partially rival. ${ }^{2}$ Our results confirm that information diffusion is far from perfect even in the absence of such considerations.

Our findings have far-reaching policy implications. Mobile telephony has revolutionized the way many activities are conducted. This is particularly true in parts of the developing world - such as sub-Saharan Africa - where the penetration of mobile phones massively increased in recent decades. A growing number of policy interventions employ mobile phone messages to pursue a development objective. Some of these messages nudge recipients into taking a particular action - e.g., saving reminders (Karlan, McConnell, Mullainathan, and Zinman, 2016; Blumenstock, Callen, and Ghani, 2016; Abebe, Tekle, and Mano, 2016), debt repayment (Karlan, Morten, and Zinman, 2012; Afzal, d'Adda, Fafchamps, Quinn, and Said, 2018), or preventive health (Obermayer, Riley, Asif, and Jean-Mary, 2004; Patrick, Raab, Adams, Dillon, Zabinski, Rock, Griswold, and Norman, 2009; Raifman, Lanthorn, Rokicki, and Fink, 2014). Other interventions have taken the form of information and awareness campaigns. Recent examples include information about: agricultural prices (Fafchamps and Minten, 2016); water quality (Okyere, Pangaribowo, Asante, and von Braun 2017); and the electoral process (Aker, Collier, and Vicente, 2017). ${ }^{3}$

Such interventions have the potential of reaching beyond the immediate recipient of the message. Many policy interventions have long sought to increase their impact by relying on diffusion among peers. A number of recent studies have tested whether such interventions diffuse along social networks (e.g., Banerjee, Chandrasekhar, Duflo, and Jackson, 2013, 2016; Fafchamps and Vicente, 2013; Fafchamps, Vaz, and Vicente, 2017; Comola and Prina, 2017). IT can potentially make diffusion among peers much easier because messages (e.g., SMS, email, tweet, Facebook post) can easily be re-posted or forwarded to others. Its potential is further strengthened by the introduction of mobile money, as illustrated in our experiment.

While most development actors recognize the potential for running inexpensive nudging or information campaigns through IT, we know little about whether recipients actually read or believe the messages they receive, and whether they forward these messages to others. This

\footnotetext{
${ }^{2}$ There is a limited number of movie tickets, allocated to the first fifty winners only.

${ }^{3}$ Mobile phones have also been used to conduct surveys (e.g., Garlick, Orkin, and Quinn, 2016).
} 
paper fills this lacuna while suggesting ways of increasing the effectiveness of such interventions and encouraging the circulation of valuable information to others.

The paper is organized as follows. In section 2, we describe our experimental design, including network structure, base game, treatments, game sequence, sampling and randomization, and testing strategy. Implementation details are presented in section 3 while descriptive results and regression analysis of redeeming and sending behavior are discussed in Section 4. Concluding remarks are given in the final section.

\section{Experimental design}

The treatment to which subjects are exposed - i.e., receiving by SMS valuable information that can be shared with others - is similar to many policy interventions in developing countries. The purpose of our experimental design is to test two main assertions: people believe truthful and valuable information received from a stranger; and people are willing to share information that is potentially valuable to strangers. Like in Centola (2010), we randomly assign subjects to a set of strangers with whom they can share valuable information. They cannot share it with anybody else. The purpose of this design feature is to eliminate possible confounding effects due to differences in social networks across individuals.

We investigate a number of secondary hypotheses. First, we vary the amount of information that people have on recipients and senders. We hypothesize that people may be more willing to share valuable information with people with whom they can identify. Second, we vary the cost of sending the vouchers to others and the set of alternative actions. Specifically, we allow senders to pass information they know to be untrue. If information sharing is motivated primarily by altruism, we would not expect the sharing of untrue messages. But if senders have invidious or rival preferences - or are mischievous - we would observe the circulation of erroneous messages. Third, it has often been noted that sharing valuable information with others generates a sense of gratefulness, and triggers a desire for the recipient to reciprocate. To capture these ideas in a stylized manner, we introduce treatments that allow the sender to impose, solicit, or receive a payment. We hypothesize that information sharing improves when it is incentivized.

In the remainder of this section we present the experimental design in detail. We first describe the network structure used throughout the game. We then discuss the base game and the different treatments. The game sequencing is presented next, followed by the testing strategy.

\subsection{Network}

For the purpose of this study we construct a simple network of 192 individuals with access to mobile money. This network is composed by 12 groups of 16 individuals, which we call squares. Note that, in our design, we make sure that individuals in the same square are initially unrelated to each other, and that individuals in different squares are not connected in our constructed network. 
As illustrated in Table 1 , a square is a $4 \times 4$ grid of 16 subjects $I_{r p}$ where $r$ denotes the round and $p$ denotes the position in the round. We build information sharing links between rows of the same square as follows: each element in row 1, i.e., subjects $I_{11}$ to $I_{14}$, is connected with each element of row $2, I_{21}$ to $I_{24}$; each element in row 2 is also connected with each element of row $3, I_{31}$ to $I_{34}$; and each element in row 3 is connected with each element of row $4, I_{41}$ to $I_{44}$.

All contacts between participants take place through text messages mediated by the experimenter, i.e., subjects pass information to each other by using text messages relayed by our switchboard from one subject to another. Subjects are never told the identity or phone number of the person with whom they are sharing information. All the messages received by participants come from the switchboard and are written in Portuguese - see the Appendix for the full list of messages used in the experiment, together with their English translation. For each message sent, an experimental subject incurs a cost of 1-2 Meticais charged by the phone operator. ${ }^{4}$ In compensation for this - and their participation time - each subject receives a participation fee of 70 Meticais paid in mobile money at the end of the experiment. In the year of the experiment 1 USD was approximately equivalent to 35 Meticais.

All games and treatments are implemented at the level of the square - which thus plays the same role as a session in a lab experiment. Each round takes approximately 24 hours, i.e., subjects in a round have 24 hours to redeem the voucher and to share it with up to four others. This basic structure applies to each game, with some differences across treatments described below. We start by describing the base game in more detail at the level of a square, before turning to the different treatments, each implemented on different squares.

\subsection{Base game}

The base game (game 0) starts with the seeding round, i.e., round 1. In this round, after an introductory message by the experimenter, each individual in the first row of the square - i.e., $I_{11}$ to $I_{14}$ - receives an SMS from the experimenter asking whether they want to receive 35 Meticais - i.e., approximately 1 USD - on their mobile money account. To receive the money, the subject has to send a message back with the word 'yes'.

Each round 1 subject then receives messages asking if he/she wants us to give the same voucher to round 2 participants. Subjects receive four such messages, one for each of the four round 2 participants. To instruct us to send the voucher to this other person, the subject has to reply with an SMS containing the word 'yes'. Since each of the four senders in round 1 can send the voucher to each of the receivers in round 2 , subjects in round 2 can receive up to four vouchers. Those who do not receive any voucher SMS from round 1 participants are dropped from the game. The remaining first receive an introductory message from the experimenter before receiving the voucher SMS itself. In round 2 this SMS is worded slightly differently: it explicitly states that the voucher is sent at the request of another participant in the experiment.

\footnotetext{
${ }^{4}$ Virtually all subjects in our experiment use pay-as-you-go. Phone operators run occasional promotions of the form 'Earn X free SMS if you top up your account by Y Meticais'.
} 
Since there are four round 1 subjects who could have sent the voucher, a round 2 subject can receive it up to four times 35 Meticais. To receive the money, the subject has to reply to each of these messages with the word 'yes'. After this, round 2 subjects receive messages asking if they want us to give the same voucher to round 3 participants. As in round 1, they receive four such messages, one for each round 3 participant, and they have to reply 'yes' by SMS. Based on these responses, a list is drawn of those round 3 subjects who are to receive the voucher SMS. Round 3 follows the same structure as round 2. Round 4 starts in the same way: subjects $I_{41}$ to $I_{44}$ receive the voucher SMS for each of the round 3 subjects who has instructed us to do so. But since this is the last round, they are not asked about sending the voucher to other players.

Each request by the experimenter, i.e., on receiving the voucher or sending it, had to be answered within 24 hours to be considered admissible. Messages that are received after the deadline are ignored. ${ }^{5}$ This is to ensure that each square follows a similar sequencing - similar to what happens in a lab experiment. Using four separate phone numbers - one for each of the four receiving and four sending decisions - makes it possible to identify the sender and intended recipient of each of the messages we receive on our switchboard. Payoffs are all paid on the mobile money account of each subject at the end of the game.

There are two variants of the base game: anonymous and informed. In the anonymous variant, no information is provided to either sender or receiver: all the sender knows is that another participant to the study will receive a voucher SMS similar to the one the sender received; similarly, all that the receiver knows is that another study participant has instructed us to send him/her a voucher SMS.

In the informed variant, the sender is told some of the characteristics of the receiver - namely, their gender, age, schooling, and income category. The receiver is given analogous information about the sender. Gender is implied by the first name of the sender or receiver (which is spelled out in the message); age is given in years; education is given in years of completed schooling (up to 12th grade) or the type of post-secondary education; and income is given as one of seven possible categories of monthly income. In contrast, in the anonymous variant, individuals in the next round are referred as 'Person $p$ ' with $p=1, \ldots, 4$.

\subsection{Treatments}

There are two groups of three games in addition to the base game, forming six treatments in total. The first group of three (games $1 / 2 / 3$ ) is similar to the base game but varies the price and the default selection for the voucher sending decision. The games in the second group of three (games 4/5/6) are adaptations of the dictator, ultimatum, and reverse dictator games to our setting. These treatments introduce the possibility of transfers between sender and receiver in exchange for the voucher. We now provide the details of each of these six games. Each of them is played on a square, just like the base game.

\footnotetext{
${ }^{5}$ Very few attempts were made to redeem after the 24 hours window expires. At the time of the study, it was extremely unlikely to lose phone service for more than an hour in Mozambique.
} 
Game 1 (variable cost of sending) varies the price of sending the voucher to another subject. This price can take four values: 0 (as in the base game), 5, 10, or 15 Meticais. This price is paid per message and comes on top of the actual cost of sending an SMS. Each subject faces each of the four different prices, one for each of the subjects in the subsequent round, in a randomized order. Strictly positive prices are deducted to game payoffs sent to subjects' mobile money accounts at the end of the game. In all other respects, this game is the same as the base game. By varying the price of sending the voucher, we can infer how much people are willing to pay for sending valuable information to others.

Game 2 (shaming and fixed cost of sending) presents subjects with a different default option when sending vouchers to others. In the base game and in game 1, if the subject does not respond to the sending SMS, the experimenter does nothing - i.e., no voucher is sent to the potential recipient. In contrast, in game 2 the default is that the experimenter sends a message to the recipient explicitly informing that the sender was given an opportunity to send the voucher but sent no valuable information. In this game, the cost of sending is set equal to 5 Meticais - in addition to the phone operator's cost of the SMS. The rest is as in the base game. The purpose of this treatment is to increase the psychological cost of not sending the voucher to others. Put more bluntly, it shames the sender for failing to send the voucher. This cost could be particularly relevant in the informed variant of the game.

Game 3 (erroneous code message and fixed cost of sending) adds a second default option to game 2 when subjects are asked about the sending of vouchers. As in games 0 and 1, if the sender does not reply, no message is sent to the recipient. If the sender responds 'yes', the voucher SMS is sent to the recipient and a fixed price of 5 is deducted from the sender's payoff (like in game 2). The sender can also respond 'no', in which case, the receiver gets an SMS containing an erroneous code that cannot be redeemed for money. ${ }^{6}$ The rest is as in the base game. The purpose of this treatment is to disentangle an explicit decision not to share - e.g., motivated by rival or invidious preferences - from simple inaction, as in game 2: if not sending the voucher manifests a desire to hurt someone, sending an erroneous message would fulfill this desire even better - albeit, here, at the small cost of sending an SMS.

The purpose of games $4 / 5 / 6$ is to introduce a market element in the sharing of information. The idea is that the sender of valuable information may either appropriate the information for their own benefit or extract a compensation from the recipient. This is captured in three stylized ways. The three games are based on the dictator, ultimatum, and reverse dictator games, respectively. The details are as follows.

Game 4 (dictator) adapts a standard dictator game to our setting. In this game, a subject is asked to share a 35 Meticais voucher between themselves and one other subject in the subsequent row of the square. Each row 1 subject does this four times, once for each subject in row 2 . In other words, each subject in row 1 receives 35 Meticais four times, and each time the subject can share that amount with one different subject from row 2. These decisions are then combined

\footnotetext{
${ }^{6}$ To avoid deceiving the subject, this is made clear in the message sent to the recipient - see Appendix for details.
} 
to calculate the total payoff of the sender. If the sender does not respond to one of the four messages, this is treated as equivalent to sending nothing, in which case the sender keeps the 35 Meticais. This is different from a standard dictator game where there is no default option and the subject is forced to pick a division of the pie. If the subject does not respond to any of the four messages, he/she receives $35 \times 4=140$ Meticais.

The exact same decision structure is repeated in round 2: the experiment sends 35 Meticais four times to each round 2 subject, and each time the round 2 subject can share part of it with a round 3 subject. The same is again repeated in round 3. Subjects in row 4 do not decide anything; they just receive what row 3 subjects choose to send them. As in the base game, subjects in rounds 2 to 4 do not receive any message if nothing is sent to them by previous participants. The idea behind this aspect of the design is to investigate how far information diffuses in the network.

In this treatment, the sender is given the opportunity to appropriate the entire value of each voucher. The purpose of this is to determine the extent to which subjects are willing to share something valuable instead of appropriating it. If the subject does nothing, this is treated as not sharing. Furthermore, if the sender does nothing, the recipient is not informed that the sender had an opportunity to share. These differences with the standard dictator game are introduced into our design to capture the fact that, in practice, sharing information requires a deliberate action - doing nothing is the default - and if someone does not share valuable information, potential recipients typically do not learn of it.

Game 5 (ultimatum) adapts an ultimatum game to our framework. It is similar to game 4: each subject in rounds 1 to 3 is asked four times to share 35 Meticais between themselves and one subject in the next row. The difference is that, in this treatment, the designated receiver can refuse the share sent by the sender. If the receiver refuses what the sender offered, both sender and receiver get nothing of the 35 Meticais. Each receiver has to make this decision each time he/she receives an offer to share 35 Meticais. If the sender does not make any offer to a particular recipient - i.e., does nothing - this is treated as a rejection by the sender, and both subjects receive nothing. This introduces an important difference with game 4 , but this is unavoidable: in order for the receiver to have an opportunity to reject an offer, an offer has to be made. If the receiver does not agree to an offer - or does nothing - this is treated as a rejection by the receiver, and both subjects also receive nothing. This treatment mimics a market for information in which the seller sets a take-it-or-leave-it price.

Game 6 (reverse dictator) is similar to game 4 except that it is the receiver who decides how much to send back to the sender. Round 1 is exactly the same as in the base game: subjects choose whether to redeem the voucher and whether to send vouchers to each row 2 subjects. Subjects in round 4 only decide how much to send back. Subjects in rounds 2 and 3 decide both how much to send back to the sender from the previous row (first) and whether to send a voucher to the receiver in the subsequent row (second). Unlike in the base game, subjects do not have to respond 'yes' to the voucher SMS in order to receive it - they are only asked to determine how much they wish to send back. If a subject does not respond, he/she is assumed 
to send back nothing - which is the mirror image to the sender's decision in game 4: doing nothing is equivalent to appropriating the whole voucher. As in the base game, a subject in rows 2 to 4 only participates to the game if at least one subject from the previous row decided to send him/her a voucher. Note that game 6 is not strictly equivalent to a reverse dictator in the sense that the receiver knows that the voucher was sent by the sender. This important distinction may create a reciprocity effect that mimics the 'pay-what-you-want' market model as practiced by certain websites.

\subsection{Game sequence}

In our experiment, each square - or group of 16 subjects - plays four different games sequentially. The first game is always the base game (game 0 ). The other three games are either games $1 / 2 / 3$ or games $4 / 5 / 6$. We implement these two sets of games on the same subjects so we can achieve identification within subjects. The 12 squares are divided equally into two sets of 6 : those playing games $1 / 2 / 3$ and those playing games $4 / 5 / 6$. Each set of six is further divided into two groups of three: one always play anonymous games; the other always plays informed games. Within each group of three squares, the order of the games is varied systematically. To summarize, the assignment structure of games to squares is as follows in Table 2, where Gi stands for game $i$ and $A / I$ stands for Anonymous/Informed.

\subsection{Testing strategy}

We divide our analysis between the decision to receive mobile money from others, and the decision to send mobile money to others. In each case, we test for differences between the different games, whether sender and receiver were fully anonymous, and whether sending and receiving vary systematically with subject characteristics.

In addition to reporting average choices for each game, we also report results from a regression analysis. For receiving or redeeming vouchers, we use the following core specification:

$$
R_{i j r t}=\alpha+\beta_{1} G_{i j r t}^{1}+\beta_{2} G_{i j r t}^{2}+\beta_{3} G_{i j r t}^{3}+\gamma I_{i}+\delta_{r}+\varepsilon_{i j r t}
$$

where the dependent variable $R_{i j r t}$ is a binary variable taking value 1 in case subject $i$ redeemed a voucher opportunity sent by subject $j$ in round $r$ and period $t$. Regressors are as follows: $G_{i j r t}^{k}$ is a game $k$ dummy; $I_{i}$ is a dummy equal to 1 in the informed (or non-anonymous) variant; and $\delta_{r}$ is a vector of round and period dummies, included to control for the possibility that experimental fatigue or loss of attention affects our findings.

We focus our attention on games $0 / 1 / 2 / 3$ in regression (1.1) since redeeming decisions are either absent or of minor importance in games $4 / 5 / 6$. We also estimate a specification that adds prior redeeming (in earlier periods) to see whether a positive experience with redeeming in an earlier period spurs more confidence in voucher messages.

To test for homophily we estimate a model that includes absolute differences $\left|X_{i}-X_{j}\right|$ 
in individual characteristics $X$ between subject $i$ and the subject $j$ from whom $i$ received the voucher. ${ }^{7}$ We only use the four characteristics $X_{i}$ that are revealed to $i$ about $j$ - and vice versa. Since pairwise characteristics are only revealed to subjects in the non-anonymous treatment, $\left|X_{i}-X_{j}\right|$ is interacted with the non-anonymous treatment dummy $I_{i}$. When estimating this regression we also include characteristics $X_{i}$ and absolute differences $\left|X_{i}-X_{j}\right|$ as additional controls. $^{8}$ The estimated regression is thus of the form:

$$
\begin{aligned}
R_{i j r t}= & \alpha+\beta_{1} G_{i j r t}^{1}+\beta_{2} G_{i j r t}^{2}+\beta_{3} G_{i j r t}^{3}+\gamma I_{i} \\
& +\theta\left|X_{i}-X_{j}\right| I_{i}+\mu X_{i}+\lambda\left|X_{i}-X_{j}\right|+\delta_{r}+\varepsilon_{i j r t}
\end{aligned}
$$

Homophily implies $\theta<0$ - i.e., the more dissimilar $i$ and $j$ are, the less $i$ is willing to redeem a voucher from $j .{ }^{9}$ When estimating regression (1.2), we only include redeeming decisions that apply to SMS vouchers received from another subject - i.e., we drop observations from round 1 subjects who receive the voucher from the experimenter.

For sending, the baseline specification for games $1 / 2 / 3$ takes the following form:

$$
S_{i j r t}=\alpha+\beta_{1} G_{i j r t}^{1}+\beta_{2} G_{i j r t}^{2}+\beta_{3} G_{i j r t}^{3}+\theta C_{i j t}+\gamma I_{i}+\delta_{r}+\varepsilon_{i j r t}
$$

where the dependent variable $S_{i j r t}$ is a dummy equal to 1 in case subject $i$ sends a voucher opportunity to subject $j$ in round $r$ and period $t$. Variable $C_{i j t}$ is the cost of sending the voucher to another subject which, in games $0 / 1 / 2 / 3$, varies exogenously by subject pair $i j$. We also estimate a specification that includes the redeeming decision as additional control, and a specification that adds $\left|X_{i}-X_{j}\right|$, and controls $X_{i}$, to test for homophily in sending decisions.

For the decision to send or send back money in games $4 / 5 / 6$, we use a similar specification of the form:

$$
S_{i j r t}=\alpha+\beta_{5} G_{i j r t}^{5}+\beta_{6} G_{i j r t}^{6}+\beta_{6 b} G_{i j r t}^{6 b}+\gamma I_{i}+\delta_{r}+\varepsilon_{i j r t}
$$

where the game dummy $G$ superscript 6 refers to the decision to send in game 6 while $6 b$ refers to the decision to send back in the same game. The specification is similar to (1.3), except that we do not include the cost of sending since it is constant. We also estimate a specification that adds $\left|X_{i}-X_{j}\right|$ and controls $X_{i}$, again to test for homophily. The amount sent is examined in a separate regression. In most specifications, we estimate linear probability models and report robust standard errors.

\footnotetext{
${ }^{7}$ To facilitate interpretation, when $X_{i}$ is a dichotomous variable - e.g., gender - we replace the absolute difference with a dummy equal to one if $i$ and $j$ have the same gender, and 0 otherwise.

${ }^{8}$ For instance, $\left|X_{i}-X_{j}\right|$ may be systematically larger when $X_{i}$ is large.

${ }^{9}$ When the regressor is a dummy equal to 1 if $i$ and $j$ share a characteristic - e.g., gender - the interpretation is reversed.
} 


\section{Implementation}

We implemented the design as a lab-in-the-field experiment in Mozambique in May to July, 2015. Participants are recruited among the heads of households and their spouses who took part in a study on the introduction of mobile money in rural Mozambique (Batista and Vicente, 2017). The original sample was constructed using a representative sample of rural enumeration areas with mobile phone coverage in the provinces of Maputo Province North, Gaza, and Inhambane. Within each of the 102 enumeration areas sampled for that study, an average of 11 households per enumeration area was selected through a random walk process - i.e., by walking from the center of the enumeration area in different direction and inviting each $n$-th house along the way to participate in the study. The original sample was selected in 2012 and was followed as a panel until 2015, with several survey rounds (the last of which in mid-2014). In half of the sample, i.e., in 51 enumeration areas, mobile money was introduced through the recruitment of a local agent and the organization of various dissemination activities at the enumeration area level. Within these locations, a random sub-sample was targeted for individual dissemination of mobile money. By design, participants to the experiment are more knowledgeable than the average Mozambican about mobile phone communication and mobile money services.

In this paper we focus on individually-treated individuals of the original sample. This ensures that all participants had previously been introduced to mobile money, had used the service, and had a mobile money account on their mobile phone at the time of the experiment. Most of the 192 individuals in our study were recruited by phone or SMS. Some were recruited through face-to-face contact. Informed consent was obtained at the time of recruitment. Subjects were then reminded of the experiment by SMS just before starting game 0. We should point out that the mobile phone operator sends marketing SMS's to individual subscribers on a regular basis. While this increases the possibility that our messages are misconstrued as spam, it also raises the external validity of our findings, since any information campaign using SMS services in Africa is bound to encounter the same problem.

The division of the 192 participants into 12 squares follows a random procedure that ensured that no two subjects from the same enumeration area are allocated to the same square. This is done to avoid the possibility of direct communication between subjects. The last survey round held in mid-2014 is the source of information for individual characteristics employed in the non-anonymous variant.

Funding for the research was provided by the International Growth Center. The experiment was implemented in collaboration with Carteira Móvel/Mkesh and the Novafrica office in Mozambique. All messages were sent and relayed by research assistants recruited for the project. 


\section{Empirical analysis}

\subsection{Descriptive statistics and balance}

Key characteristics of the sample are presented in Table 3. Approximately 59 percent of participants are female, and the average participant is 40 years of age. The average number of years of education is 6 (if equal or below 12), with most subjects having no higher education (96 percent). Average monthly income is 3,445 Meticais, which is approximately equal to 98 USD per month.

The rest of Table 3 tests for balance across experimental treatments. We begin by comparing each pair of squares in terms of demographic characteristics. Across the 330 differences we tested (66 pairwise tests $\times 5$ variables), we find a total of 19 that are statistically significant at the 10 percent level - well below what would be expected to occur by chance (10 percent).

We also report the test of joint significance of square dummies to check for systematic differences between squares. In addition, we compare the two halves of our sample, namely those playing games $1 / 2 / 3$ and those playing games $4 / 5 / 6$. Within each of the two halves of the sample, balance across games is achieved by experimental design - see Table 2. We also compare subjects in non-anonymous and anonymous treatment squares. All these tests fail to reject the null hypothesis of no difference for each of the observable characteristics considered. Randomization thus appears to have achieved balance on key individual characteristics across squares and treatment blocks.

\subsection{Average behavior}

We report in Tables 4 and 5 the average behavior of the subjects in the base game and each of the six treatments. Note that some actions are not relevant in some treatments, e.g., receiving is automatic in game 4 , and sending back is only a possible action in game 6 .

We first examine what happens in the base game. We observe that the number of redeeming observations is lower than 192, the sample size. This is because, despite the fact that several (up to four) vouchers could be potentially redeemed in rounds 2-4, many subjects in late rounds never receive any voucher. The number of sending observations is higher than the number of redeeming observations because each subject who receives a voucher in rounds 1-3 is automatically given the option to send it to four other subjects.

We find that the probability of redeeming the voucher is 26 percent, while the probability of sending the voucher to any of the four players in the next row is 24 percent. This indicates that a large proportion of participants do not accept what is essentially a 'free lunch': indeed, by sending a 'yes' SMS at a cost of 1-2 Meticais, they would have received 35 Meticais. The voucher redemption rate appears particularly low given the facts that we secured explicit agreement from all participants for participating in the experiment, and that we took care to remind each participant individually shortly before the base game that messages would follow containing opportunities to earn money. 
In contrast, the propensity to send appears relatively high, given the costs of sending messages and the absence of material benefit for the sender. One possible interpretation is that sending follows a 'warm glow' motivation: subjects seem keen to share with others a valuable opportunity, even if they themselves do not value it highly. Some evidence to this effect comes from observing that, among the players given the opportunity to both redeem and send vouchers, 11 percent send at least one voucher but do not redeem themselves. Together they represent 33 percent of the subjects who send any voucher.

Turning to the difference between the non-anonymous and anonymous versions of the base game, we see higher redeeming and sending for the anonymous version. These findings will be shown to be statistically significant when we employ regression analysis in the next subsection. For redeeming, we also note a slightly higher rate in round 1 (redeeming a voucher received from us) compared to rounds 2-4 (redeeming a voucher received from another subject).

Columns 2-4 of Table 4 present average redeeming and sending decisions in games 1-3. Note that, as explained earlier, the order of the three games varies randomly across squares, i.e., they are not necessarily played in the order in which they appear in the table. We observe a dramatic drop in both redeeming and sending behavior in all three games relative to the base game. The voucher redemption rate falls by between 27 (game 3) to 49 (game 1) percent, even though the cost of redemption is the same. Possibly because the cost of sending is higher, sending falls too, by between 41 (game 1) to 74 (game 3) percent. But contrary to expectations, sending is most common in game 1, for which the cost of sending is, on average, highest. The propensity to send is lower in game 2 than in game 1 - suggesting that changing the default to an erroneous message did not create a psychological pressure to give. This is reminiscent of situations (e.g., DellaVigna, List, and Malmendier, 2012) in which individuals give because they perceive a moral pressure to do so but feel exonerated if a device (in our case, a default message of an erroneous voucher) takes an action for them. In game 3 subjects could either pay 5 Meticais to send an SMS voucher to the receiver, send an erroneous voucher message, or do nothing. In practice, we only observe two cases of subjects sending an erroneous voucher message, making this game similar to game 1 , with a slightly lower cost of sending on average. We nonetheless observe a further decrease in the sending probability, which now falls to 6 percent. One possible explanation is that the introduction of an irrelevant but selfish alternative prompts subjects to act selfishly. We note that, like for the base game, anonymous versions of games 1-3 tend to yield higher redeeming and sending rates than their non-anonymous counterparts.

In games 4 to 6 the primary emphasis is on sending decisions. To recall, in games 4 and 5 , senders decide an amount to be sent. In game 6 they decide whether to send the voucher or not. In game 4 receivers do nothing. In game 5 , receivers can either accept or reject take-it-or-leave-it offers. In game 6 , receivers decide whether to redeem a voucher from the experimenter in round land then whether and much to send back of the voucher to the sender. We report on all these choices in Table 5.

In game 4 the sender appropriates the full value of the voucher by doing nothing. We see that introducing this possibility leads to a fall in the propensity to send something to the receiver: 
from 24 percent in the base game to 15 percent in game 4 . These differences are statistically significant. They suggest that when senders cannot appropriate the voucher, they are willing to spend some of their own money to benefit someone else, and when they can appropriate the voucher, many prefer doing so to sending anything. We also note that, even when they send something, subjects only give around 27 percent of the value of the voucher on average. Across all subjects and decisions, senders retain more than 96 percent of the voucher value.

In game 5, sending something introduces a risk: the receiver may refuse the offer - something that occurs in 43 percent of the cases. We observe an 18-percent probability of sending money to the receiver, lower than in game 0 and only slightly higher than game 4 . This is a priori surprising because, in game 5 , the sender receives nothing if no offer is made. This suggests reluctance to make an offer that can be rejected by the receiver - and indeed offers are rejected a large fraction of the time. We also note that the amount sent does not increase relative to game 4.

In game 6 , the sender can only elect to send or not the entire value of the voucher to the receiver, as in game 0 . We find that the probability of sending in this case is identical to game 0. This suggests that the prospect of receiving something back from the receiver does not incentivize senders to send more. In 12 percent of the cases, the receiver elects to send something back, i.e., at a rate that is broadly similar to what senders do in game 4 . But when they do, they send back a much higher proportion of the voucher value - typically almost all of it, suggesting, among these subjects, a reciprocity motive. Senders in round 1 are also given the choice to redeem or not the voucher sent by the experimenter. 38 percent of subjects do so. Finally we note that, as in Table 4, anonymous versions of the games 4 to 6 cause higher sending rates.

\subsection{Redeeming the voucher}

To fully assess the determinants of redeeming vouchers in games $0 / 1 / 2 / 3$, we regress the redeeming decisions on treatment variables as specified in the section on testing strategy. The dependent variable is a dummy equal to 1 if the subject sends a 'yes' SMS in response to a voucher offer, and 0 otherwise. The results are shown in Table 6. Column (1) reports the results from regression model (1.1). ${ }^{10}$ In column (2) we add a dummy variable with value 1 if the subject redeemed a voucher in a previous game: subjects who trust the SMS enough to redeem it in one game should also be more likely to trust it in a subsequent game. Column (3) reports estimates for model (1.2) that test for homophily. In addition to regression coefficients, at the bottom of Table 6 we report test statistics of the null hypothesis that there is no difference between pairs of treatments.

Regression analysis confirms that the probability of redeeming decreases between the base game and the other three games, although, for game 3, this is only significant in column (2).

\footnotetext{
${ }^{10}$ The non-anonymous dummy, for the analysis of redeeming, always takes value 1 (non-anonymous) for round 1 since subjects knew that vouchers originate from the experimenter at that point.
} 
Pairwise comparisons reported at the bottom of Table 6 nonetheless indicate that we cannot reject the hypothesis that redeeming is equally likely under games 1,2 and 3. The reduction in redeeming is large relative to the counterfactual probability of redeeming in game 0 : the probability of redeeming drops by 18 to 30 percentage points in games 1 and 2, and by 21 percentage points in game 3 .

As already observed in Table 4, we find a large reduction in redeeming associated with the non-anonymous variant: around 20 percentage points when considering the main specifications in columns (1) and (2). This confirms that subjects are more likely to redeem a voucher that comes from an anonymous source. We also observe more redeeming in round 1 , that is, when the voucher originates from the experimenter, than when the voucher comes from another subject. This further confirms that messages are more trusted when they come from a more anonymous source, which is a priori counter-intuitive. We do not find systematic period effects.

Since game payoffs are deposited on subjects' mobile money account at the end of each game period, subjects who redeem in a given period receive the voucher money at the end of that period. This should make them more confident of receiving the voucher money in subsequent periods. We therefore expect redeeming behavior to be persistent. This is indeed what we find: there is a strong positive correlation between redeeming now and redeeming in a previous period. We cannot, however, rule out the possibility that captures differences in trusting behavior across subjects.

When adding pairwise regressors (column 3), point estimates suggest that subjects are more likely to redeem a voucher received from a person of the same gender and education level. But none of these effects is statistically significant. ${ }^{11}$ From this we conclude that there is no conclusive evidence of homophily in redeeming decisions. Perhaps this is not too surprising given that there is on average less trust in the non-anonymous version of the game. From the estimated coefficients of individual characteristics $X_{i}$, we also note that older subjects redeem less and richer participants redeem more. This could be because individuals who are younger and richer are more familiar with mobile phones and more willing to risk 1-2 Meticais for the prospect of receiving 35 Meticais.

\subsection{Sending the voucher}

We report in Table 7 a similar analysis for the decision to send the voucher to another participant in games $0 / 1 / 2 / 3$. The dependent variable is a dummy equal to 1 if the subject sends an SMS instructing the experimenter to send a voucher SMS to another subject. To recall, there are four such decisions per voucher recipient, one for each of four possible recipients in the next row of Table 1. We include as regressor the cost of sending the SMS which, to recall, varies between $0 / 5 / 10 / 15$ Meticais across subject pairs $i j$ in game 1 . This cost is a constant at 5 Meticais in

\footnotetext{
${ }^{11}$ Similar results (not shown here) are obtained if we estimate an individual fixed effect model that compares redeeming behavior across different senders for the same receiver. Because the number of subjects who receive multiple SMS vouchers is relatively small, however, the number of observations is small and statistical power is limited.
} 
games 2 and 3, and 0 in the base game. Column (1) reports coefficient estimates for specification (1.3). In column (2) we add two redeeming dummies - one for the previous period, as in Table 6 ; and one for the current period, just before the decisions to send. The purpose of this addition is to test whether subjects are more likely to send a voucher that they themselves redeem as would be the case if sharing is done primarily by those who trust the message enough to redeem it. Column (3) includes $\left|X_{i}-X_{j}\right| I_{i}$ and related controls as additional regressors to test for homophily in sending choices.

As noted when discussing Table 4, we observe a strong reduction in the sending probability between game 0 and the other three games. These differences are all statistically significant at the 1 percent level and large in magnitude, ranging between 9 and 26 percentage points, depending on the specification. Given that sending is more costly in games $1 / 2 / 3$ than in game 0 , these findings suggest that sharing information is cost sensitive. However, the cost of sending a message, which varies randomly in game 1 , has no significant effect on the probability of sending a voucher, casting some doubt on the hypothesis that cost differences is the only cause for the difference between game 0 and games $1 / 2 / 3$. As in Table 6 , we find less sending in rounds 2 and especially 3 , possibly indicating a reluctance to forward messages received from other subjects instead of from the experimenter.

The results further indicate that sending the voucher is less likely in games 2 and 3 than in game 1. In game 2, when the sender chooses not to send the voucher, the recipient receives a message saying that the sender had the option to send something but did not. This can be seen as an attempt to shame the sender for not sending valuable information, in the hope of increasing information sharing. This attempt appears to backfire: if anything this treatment reduces sharing. The difference between games 1 and 2 is not, however, statistically significant (see bottom of Table 7). We do, however, find that sending the voucher is significantly less likely in game 3 than in game 1 . To recall, game 3 is when the sender has the opportunity to alert the recipient that the sender chose not to share the voucher. While this almost never happens, senders may anticipate that information is less likely be trusted (even though there is not evidence of this in Table 6 ) and decide not to incur the cost of sending it. Alternatively, they may find the choices confusing and, perhaps, distasteful, and opt not to participate. Whatever the reason, this treatment reduces information sharing.

In column (2) we see that individuals who have redeemed a voucher in the past or current period are more likely to send it. The estimated coefficient is largest for those who redeem in the current period. Since subjects only find out whether the promised transfer materialized on their account at the end of the period, this correlation cannot be driven by having received the voucher. Rather, it suggests either that those who redeem are more attentive to the experiment, or that those who trust our message more are more likely to both redeem it and share it.

We again find that sending is less likely in the non-anonymous variant. The effect is large: an 8 percentage point reduction in information sharing in column (1), compared to an anonymous probability of sharing of 30 percent in game 0 . This suggests that participants are more willing to share information in an anonymous setting. Because redeeming is also lower in the non- 
anonymous treatment, controlling for past and current redeeming behavior in column (2) absorbs the effect of the non-anonymous dummy.

To investigate the role of anonymity further, we reestimate specification (1.3) with additional regressors to test for homophily. If the reluctance to share information comes from the sender realizing that the prospective recipient is different from him/her, the non-anonymous treatment effect should vanish for subject pairs who have similar characteristics. This is not really what we find: differences or similarities between sender and receiver are never statistically significant although, as in Table 6, point estimates for same gender and same education are large in magnitude. If the reduction in information sharing is not due to a reluctance to share with dissimilar individuals, then it might be due to the sender's reluctance to have his/her characteristics revealed to the recipient - i.e., the fear of being recognized. This may be particularly problematic if senders are unsure of the value of the message. Whatever the reason, subjects seem more willing to share valuable information with complete strangers.

Finally, we note that sending is more common among younger, better educated, richer participants - again consistent with these subjects being more familiar with the mobile phone technology, and being less concerned about the cost of sending a message to benefit others.

\subsection{Transfers}

We now turn to games $4 / 5 / 6$. We first estimate a model on the decision to transfer any amount, i.e., employing as a dependent variable a dummy taking value 1 if the sender sends a positive amount to the recipient, and 0 otherwise. Results are show in Table 8. Column (1) follows specification (1.4); column (2) adds pairwise characteristics to test for homophily. Note that game 6 has two sending decisions, once for the sender and once for the receiver.

From Table 5, we already know that sending is in general less frequent in games $4 / 5 / 6$ than in game 0 . This by itself suggests that information sharing is reduced when participants can get compensated for transferring valuable information. The only exception is game 6 , when it comes to the action of the sender, where the likelihood of sending money to another participant is higher. By comparing point estimates for games 4 and 6 , we see that the difference between them is large in magnitude: 15 to 16 percentage points. This makes sense: of the four sending actions taken in games $4 / 5 / 6$, sending by the sender in game 6 is the one that is most similar to sending in game 0 . The fact that propensities to send are similar in both cases indicates that giving the sender an opportunity to receive something in return does not, by itself, increase willingness to send. In contrast, in game 4, not sending anything lets the sender appropriate the full value of the voucher. This probably explains the difference between the two games.

Game 5 is similar to game 6 regarding senders' decisions: not sending anything means forfeiting the voucher. We should thus observe a similar propensity to send in both game 5 and game 6 . This is not what we observe: the frequency of sending in game 5 is similar to game 4 where the sender appropriates the voucher by not sending anything, and lower than in game 6 (sender's decision). This suggests that subjects prefer sending the information and letting the 
recipient decide whether to send something back, rather than making a take-it-or-leave it offer to the recipient and risking rejection (43 percent of offers are rejected in game 5). It follows that the fear of rejection serves as a disincentive to share.

We also observe that the probability of sending back in game 6 is not statistically different from sending in game 4: sender and receiver are equally likely to appropriate everything. This arises even though, in game 6 , the recipient knows that the sender is aware that the recipient could send something back while, in game 4, the potential recipient is not aware that the sender could have sent anything. This suggests the absence of a reciprocity motive, at least in terms of sending anything at all. More about this below. We also note that, in both game 4 (sender) and game 6 (receiver) the probability of sending is much lower than what is typically observed in a dictator game, where the modal amount shared is often around 50 percent. This difference may be due to the fact that, in both cases, appropriating everything can be achieved by picking the default option, which is doing nothing. This exonerates subjects from the moral pressure that is present in a standard dictator or reverse dictator game, where there is no default option.

Column (1) also shows that there is 6 percentage points more sending in the anonymous treatment. Turning to column (2), we again find no statistical evidence to support homophily in sending behavior - although the point estimate on same gender is large: 11 percentage points. These results are similar to those we reported in Table 7 . Taken together, this evidence confirm subjects' reluctance to share information in the non-anonymous setting. Regarding other coefficient estimates (not reported in the table to save space), we again find negative round effects - sharing is lower in rounds 3 and 4 - but no significant differences across periods - suggesting the absence of subject learning or fatigue in these games. We also find that subjects who are male, young, educated, and poorer are more likely to send something.

Table 8 focuses on the effect of treatment on the extensive margin - the likelihood of sending something. We complement these results by showing in Table 9 the effect of treatment on the intensive margin. To this effect, we present a regression of the amount sent (conditional on sending) as a function of treatments. Given the small number of non-missing observations, we only include game dummies as regressors. The results show that, conditional on giving, the amount given is by far larger for subjects who send something back in game 6 , suggestive of a reciprocity motive among the 12 percent of subjects who choose to send something back.

\subsection{Robustness}

Before concluding, we investigate the robustness of our findings to the possibility that some subjects simply ignore all the messages originating from the experiment - in spite of the fact that: all the subjects are familiar with the research team, having participated in an earlier randomized controlled trial by the same researchers; we selected subjects who are already familiar with text messages and mobile money; and we secured explicit informed consent from all the subjects shortly before the experiment began.

We first note that 31 percent of the subjects assigned to rounds 2-3-4 were never sent any 
voucher by subjects in earlier rounds. As a result, they never had the opportunity to redeem or send vouchers to other subjects. These subjects have already been omitted from the analysis. Of the remaining participants, 55 percent never actively participated in the experiment either by accepting a voucher or by sending a message to another subject. Our concern is that these subjects may have failed to participate for reasons beyond their control - e.g., they lost access to the phone number that was used to contact them. We wish to ensure that our findings - e.g., low redeeming of vouchers - are not mechanically driven by their non-activity.

To this effect, we repeat the analysis of Tables $6-8$ using only subjects who responded to at least one of our messages. We focus on the main specifications of the previous tables, i.e., with a full list of controls, and with previous redeeming behavior when considering games $0 / 1 / 2 / 3$. We omit the homophily specifications since they were never significant. Results are shown in Table 10 for games $0 / 1 / 2 / 3$ and in Table 11 for games 4/5/6. Not surprisingly, the estimated magnitude of treatment effects is larger - given that inactive subjects are omitted. But otherwise the findings are qualitatively similar to those reported in Tables 6, 7 and 8. In particular, results regarding the role of anonymity and previous redeeming are unchanged.

There are some small differences, however. We now find that sending back in game 6 is significantly more likely than in game 4 (see Table 11), consistent with reciprocity on the part of receivers in that game. We also find that sending in game 2 is significantly lower than in game 1 (see Table 10) and that high income subjects are less likely to send information to others across all treatments.

\section{Concluding remarks}

In this paper we followed a sample of rural Mozambicans with access to mobile money services. We investigated: (i) their willingness to believe valuable information they receive, and (ii) their willingness to share this valuable information with others. To this effect, we formed an exogenous network between subjects and tested a number of experimental settings implemented through SMS messages containing vouchers redeemable for mobile money.

We find that subjects have a relatively low propensity to redeem the voucher, but a comparatively high propensity to send it to others. People thus appear rather skeptical about the value of the message they receive, but this does not stop them from incurring a small cost to share it with others. Many subjects indeed share information that they do not use themselves, a behavior that can be interpreted as consistent with a warm glow motive. We nonetheless observe that both redeeming and sending are higher among subjects who previously redeemed the voucher, suggesting that they are more likely to share information if they find it trustworthy. Contrary

to expectations, anonymity increases both receiving and sending, and there is no evidence of homophily in sharing. Why this is the case is unclear. One possibility is that senders are unsure of the value of the message, and may worry others may think poorly of them for passing it on.

In terms of behavioral variation between treatments, we find that the sharing of information falls when we introduce a cost of sharing - although we do not find that subjects respond to 
small variations in price. We find no evidence that shaming helps information transfer: sharing falls when we reveal that senders send nothing, and subjects do not like to reveal that they sent nothing. We also observe less sharing in treatments that allow subjects to appropriate the value of the shared information - irrespective of the bargaining system put in place.

While these findings are informative, our study nonetheless suffers from some limitations. First, we expected that subjects would trust the voucher more, and thus that there would be more information sharing. This would have generated more usable observations among rounds 2, 3 and 4 subjects, and would have increased statistical power. Second, the SMS format imposes limitations on the information we can reasonably include in a message. This may have negatively affected the non-anonymous treatment if subjects get confused by long messages. This interpretation is difficult to distinguish from our preferred one, which assumes full understanding.

In terms of policy, this research reveals the difficulty of using mobile phone messages to diffuse valuable information in a developing country: even when participants have been sensitized beforehand and a substantial amount of money is at stake, many individuals fail to make use of the valuable information they receive. Our take-home lessons for policy-makers are: you can reach a lot of people cheaply via SMS; but do not think of it as a perfect substitute for other forms of information dissemination. When using SMS communication, think twice about doing it in a personal manner, do not attempt to shame participants into sharing with others, and do not try to reward information sharing. Instead, keep it simple.

\section{References}

Abebe, Girum, Biruk Tekle, and Yukichi Mano (2018), "Changing Saving and Investment Behavior: the Impact of Financial Literacy Training and Reminders on Micro-businesses," Journal of African Economies, 1-25 doi: 10.1093/jae/ejy007.

Afzal, Uzma, Giovanna d'Adda, Marcel Fafchamps, Simon Quinn, and Farah Said (2018),

"Two Sides of the Same Rupee? Comparing Demand for Microcredit and Microsaving in a Framed Field Experiment in Rural Pakistan," Economic Journal, doi: 10.1111/ecoj.12512.

Aker, Jenny C., Paul Collier, and Pedro Vicente (2017), "Is Information Power? Using Mobile Phones and Free Newspapers During an Election in Mozambique", Review of Economics and Statistics, 99(2): 185-200.

Andreoni, James (1990), "Impure Altruism and Donations to Public Goods: A Theory of Warm-Glow Giving," Economic Journal, 100(401): 464-77.

Bandiera, Oriana, and Imran Rasul (2006), "Social Networks and Technology Adoption in Northern Mozambique," Economic Journal, 116(514): 869-902.

Banerjee, Abhijit, Arun G. Chandrasekhar, Esther Duflo, and Matthew O. Jackson (2013), "The Diffusion of Microfinance," Science, 341(6144).

Banerjee, Abhijit, Arun G. Chandrasekhar, Esther Duflo, and Matthew O. Jackson (2016), "Gossip: Identifying Central Individuals in a Social Network," MIT, mimeograph. 
Batista, Cátia, and Pedro C. Vicente (2017), "Introducing Mobile Money in Rural Mozambique: Evidence from a Field Experiment," Universidade Nova de Lisboa, mimeograph.

Beaman, Lori, and Jeremy Magruder (2012), "Who Gets the Job Referral? Evidence from a Social Networks Experiment," American Economic Review, 102(7): 3574-93.

Beaman, Lori, Ariel BenYishay, Jeremy Magruder, and A. Mushfiq Mobarak (2015), "Can Network Theory-based Targeting Increase Technology Adoption?", University of California Berkeley, mimeograph.

Bloch, Francis, Garance Genicot, and Debraj Ray (2008), "Informal Insurance in Social Networks," Journal of Economic Theory, 143: 36-58.

Blumenstock, Joshua, Michael Callen, and Tarek Ghani (2016), "Mobile-izing Savings with Automatic Contributions: Experimental Evidence on Dynamic Inconsistency and the Default Effect in Afghanistan," University of California Berkeley, mimeograph.

Carter, Michael R., Rachid Laajaj, and Dean Yang (2016), "Subsidies, Savings and Sustainable Technology Adoption: Field Experimental Evidence from Mozambique," University of Michigan, mimeograph.

Centola, Damon (2010), "The Spread of Behavior in an Online Social Network Experiment," Science, 329(5996): 1194-97.

Comola, Margherita, and Silvia Prina (2017), "Treatment Effect Accounting for Network Changes: Evidence from a Randomized Intervention," Case Western Reserve University, mimeograph.

DellaVigna, Stefano, John A. List, and Ulrike Malmendier (2012), "Testing for Altruism and Social Pressure in Charitable Giving," Quarterly Journal of Economics, 127(1): 1-56.

Fafchamps, Marcel, Asad Islam, Abdul Malek, and Debayan Pakrashi (2017), "Can Referral Improve Targeting? Evidence from a Vocational Training Experiment," CEPR DP No. 12070

Fafchamps, Marcel, and Bart Minten (2012), "Impact of SMS-Based Agricultural Information on Indian Farmers," World Bank Economic Review, 26(3): 383-414.

Fafchamps, Marcel, Mans Soderbom, and Monique vanden Boogaart (2016), "Adoption with Social Learning and Network Externalities," NBER WP No. 22282.

Fafchamps, Marcel, and Pedro C. Vicente (2013), "Political Violence and Social Networks: Experimental Evidence from a Nigerian Election." Journal of Development Economics, 101: $27-48$.

Fafchamps, Marcel, Ana Vaz, and Pedro C. Vicente (2017), "Voting and Peer Effects: Experimental Evidence from Mozambique," Economic Development and Cultural Change, forthcoming

Foster, Andrew, and Mark Rosenzweig (1995), "Learning by Doing and Learning from Others: Human Capital and Technical Change in Agriculture," Journal of Political Economy, 103(6): 1176-209.

Golub, Benjamin, and Matthew O. Jackson (2010), "Naïve Learning in Social Networks and the Wisdom of Crowds," American Economic Journal: Microeconomics, 2(1): 112-49.

Vega-Redondo, Fernando (2007), Complex Social Networks, Cambridge University Press, Cambridge 
Garlick, Robert, Kate Orkin, and Simon Quinn (2016), "Call Me Maybe: Experimental Evidence on Using Mobile Phones to Survey African Microenterprises," University of Oxford, mimeograph.

Granovetter, Mark (1974), Getting a Job: A Study of Contacts and Careers, University of Chicago Press, Chicago

Greif, Avner (1993), "Contract Enforceability and Economic Institutions in Early Trade: the Maghribi Traders' Coalition," American Economic Review, 83(3): 525-48.

Griliches, Zvi (1957), "Hybrid Corn: An Exploration in the Economics of Technological Change," Econometrica, 25(4): 501-22.

Jackson, Matthew O. (2010), Social and Economic Networks, Princeton University Press, Princeton

Jackson, Matthew O., Tomas Rodriguez-Barraquer, and Xu Tan (2012), "Social Capital and Social Quilts: Network Patterns of Favor Exchange," American Economic Review, 102(5): 1857-97.

Kandori, Michihiro (1992), "Social Norms and Community Enforcement," Review of Economic Studies, 59(1): 63-80.

Karlan, Dean, Margaret McConnell, Sendhil Mullainathan, and Jonathan Zinman (2016), "Getting to the Top of Mind: How Reminders Increase Saving," Management Science, 62(12): 3393-411.

Karlan, Dean, Melanie Morten, and Jonathan Zinman (2012), "A Personal Touch: Text Messaging for Loan Repayment," NBER, WP No. 17952.

Mobius, Markus, Tuan Phan, and Adam Szeidl (2015), "Treasure Hunt: Social Learning in the Field," NBER, Working Paper No. 21014.

Obermayer, Jami L., William T. Riley, Ofer Asif, and Jersino Jean-Mary (2004), "College Smoking-cessation Using Cell Phone Text Messaging," Journal of American College Health, 53(2): $71-8$.

Okyere, Charles Yaw, Evita Pangaribowo, Felix Asante, and Joachim von Braun (2017), "The Impacts of Household Water Quality Testing and Information on Safe Water Behaviors: Evidence from a Randomized Experiment in Ghana," ZEF, DP on Development Policy No. 234.

Patrick, Kevin, Fred Raab, Marc Adams, Lindsay Dillon, Marion Zabinski, Cheryl Rock, William Griswold, and Gregory Norman (2009), "A Text Message-based Intervention for Weight Loss: Randomized Controlled Trial," Journal of Medical Internet Research, 11(1): e1.

Raifman, Julia RG, Heather E. Lanthorn, Slawa Rokicki, and Günther Fink (2014), "The Impact of Text Message Reminders on Adherence to Antimalarial Treatment in Northern Ghana: a Randomized Trial," PloS ONE 9, 10: e109032.

Ryan, Bryce and Neal C. Gross (1943), "The Diffusion of Hybrid Seed Corn in Two Iowa Communities," Rural Sociology, 8: 15-24. 
Round $1 \quad I_{11} \quad I_{12} \quad I_{13} \quad I_{14}$

$\begin{array}{lllll}\text { Round } 2 & I_{21} & I_{22} & I_{23} & I_{24}\end{array}$

$\begin{array}{lllll}\text { Round } 3 & I_{31} & I_{32} & I_{33} & I_{34}\end{array}$

Round $4 \quad I_{41} \quad I_{42} \quad I_{43} \quad I_{44}$

Table 1. A square

Period 1 Period 2 Period 3 Period 4

$\begin{array}{ccccc}\text { Square 1 } & G 0-A & G 1-A & G 2-A & G 3-A \\ \text { Square 2 } & G 0-I & G 1-I & G 2-I & G 3-I \\ \text { Square 3 } & G 0-A & G 3-A & G 1-A & G 2-A \\ \text { Square 4 } & G 0-I & G 3-I & G 1-I & G 2-I \\ \text { Square 5 } & G 0-A & G 2-A & G 3-A & G 1-A \\ \text { Square 6 } & G 0-I & G 2-I & G 3-I & G 1-I \\ \text { Square 7 } & G 0-A & G 4-A & G 5-A & G 6-A \\ \text { Square 8 } & G 0-I & G 4-I & G 5-I & G 6-I \\ \text { Square 9 } & G 0-A & G 6-A & G 4-A & G 5-A \\ \text { Square 10 } & G 0-I & G 6-I & G 4-I & G 5-I \\ \text { Square 11 } & G 0-A & G 5-A & G 6-A & G 4-A \\ \text { Square 12 } & G 0-I & G 5-I & G 6-I & G 4-I\end{array}$

Table 2. Game sequencing 
Table 3: Sample characteristics and balance

\begin{tabular}{|c|c|c|c|c|c|c|}
\hline & & Female & $\begin{array}{l}\text { Age } \\
\text { in years }\end{array}$ & $\begin{array}{c}\text { Years of 0-12 } \\
\text { education }\end{array}$ & $\begin{array}{l}\text { Post-secondary } \\
\text { education }\end{array}$ & $\begin{array}{l}\text { Income in '000 } \\
\text { Meticais/month }\end{array}$ \\
\hline \multicolumn{7}{|l|}{ Sample characteristics: } \\
\hline Sample mean & & $58.9 \%$ & 39.963 & 6.175 & $4.2 \%$ & 3.445 \\
\hline Sample standard error & & & $(1.003)$ & $(0.235)$ & & $(0.420)$ \\
\hline \multicolumn{7}{|l|}{ Balance across squares: } \\
\hline $\begin{array}{l}\text { Proportion of pairwise comparisons between } \\
\text { squares that are significant at the } 10 \% \text { level }\end{array}$ & & $2 / 66$ & $2 / 66$ & $7 / 66$ & $8 / 66$ & $0 / 66$ \\
\hline Joint F-test of balance across all squares & $p$-value & 0.762 & 0.818 & 0.195 & 0.126 & 0.934 \\
\hline Joint F-test that games 1-2-3 = games 4-5-6 & p-value & 0.662 & 0.632 & 0.813 & 0.481 & 0.417 \\
\hline $\begin{array}{l}\text { Joint F-test of balance across the non- } \\
\text { anonymous and anonymous treatments }\end{array}$ & $p$-value & 0.189 & 0.358 & 0.126 & 0.481 & 0.963 \\
\hline
\end{tabular}

Note: Pairwise comparison tests are obtained by regressing the variable of interest on a square dummy, using only two squares at a time, and counting how many times the dummy is significant. There are 66 (i.e., $\mathrm{N}(\mathrm{N}-1) / 2$ ) possible pairs of 12 squares. Using a 10 percent significance level, there should on average be 10 percent significant dummies (i.e., 6.6) if the null of perfect balance across all squares is true. Balance across all squares is tested by regressing the characteristic of interest on square dummies and performing a joint F-test of all dummies. Balance between games 1-2-3 and games 4-5-6 is tested by regressing the characteristic of interest on a games 4-5-6 dummy. Balance across the anonymous and non-anonymous treatment is tested by regressing the characteristic of interest on the non-anonymous dummy. P-values from these tests are reported in the Table. Robust standard errors estimated. 
Table 4: Choices made by subjects in games $0 / 1 / 2 / 3$

\begin{tabular}{ccccc}
\hline \hline & $\begin{array}{c}\text { Game 0: } \\
\text { base game }\end{array}$ & $\begin{array}{c}\text { Game 1: variable } \\
\text { cost of sending }\end{array}$ & $\begin{array}{c}\text { Game 2: shaming } \\
\text { and fixed cost of } \\
\text { sending }\end{array}$ & $\begin{array}{c}\text { Game 3: } \\
\text { erroneous } \\
\text { message and fixed } \\
\text { cost of sending }\end{array}$ \\
\hline Redeeming the voucher: & $25.9 \%$ & $13.3 \%$ & $15.8 \%$ & $18.8 \%$ \\
All subjects & $27.1 \%$ & $12.5 \%$ & $12.5 \%$ & $16.7 \%$ \\
Round 1 only (1) & $25.3 \%$ & $14.3 \%$ & $21.4 \%$ & $25.0 \%$ \\
Rounds 2-4 (2) & $21.7 \%$ & $10.7 \%$ & $12.5 \%$ & $14.3 \%$ \\
Non-anonymous & $33.3 \%$ & $17.6 \%$ & $21.4 \%$ & $50.0 \%$ \\
Anonymous & 143 & 45 & 38 & 32 \\
Number of observations & & & & $6.3 \%$ \\
Sending the voucher: & $24.2 \%$ & $14.3 \%$ & $10.1 \%$ & $6.3 \%$ \\
All subjects & $21.7 \%$ & $7.0 \%$ & $0.0 \%$ & $6.3 \%$ \\
Non-anonymous & $26.8 \%$ & $18.9 \%$ & $14.7 \%$ & 128 \\
Anonymous & 392 & 147 & 139 & \\
Number of observations & N & & & \\
\hline \hline
\end{tabular}

Note: Redeeming the voucher means responding with a 'yes' SMS to our switchboard. Sending the voucher means responding with a 'yes' SMS to an SMS invitation to share information about the voucher with another randomly selected subject. In game 3, the zero value includes both alternatives to sending. Only two subjects sent the erroneous voucher. (1) In round 1 the voucher SMS is sent at the initiative of the experimenter. (2) In rounds 2-4 the voucher SMS is sent at the request of a subject. 
Table 5: Choices made by subjects in games $0 / 4 / 5 / 6$

\begin{tabular}{|c|c|c|c|c|c|}
\hline \multirow[b]{2}{*}{ Sending the voucher: } & \multirow{2}{*}{$\begin{array}{c}\begin{array}{c}\text { Game 0: } \\
\text { base game }\end{array} \\
\text { Sender sent }\end{array}$} & \multirow{2}{*}{$\begin{array}{c}\begin{array}{c}\text { Game 4: } \\
\text { dictator game }\end{array} \\
\text { Sender sent }\end{array}$} & \multirow{2}{*}{$\begin{array}{c}\begin{array}{c}\text { Game 5: } \\
\text { ultimatum game }\end{array} \\
\text { Sender sent }\end{array}$} & \multicolumn{2}{|c|}{$\begin{array}{l}\text { Game 6: } \\
\text { reverse dictator }\end{array}$} \\
\hline & & & & Sender sent & Receiver sent back \\
\hline All subjects & $24.2 \%$ & $14.8 \%$ & $17.9 \%$ & $24.2 \%$ & $11.8 \%$ \\
\hline Non-anonymous treatment & $21.7 \%$ & $10.9 \%$ & $15.9 \%$ & $19.4 \%$ & $9.5 \%$ \\
\hline Anonymous treatment & $26.8 \%$ & $18.3 \%$ & $20.8 \%$ & $28.8 \%$ & $13.3 \%$ \\
\hline Share sent & & $3.9 \%$ & $4.3 \%$ & & $11.6 \%$ \\
\hline Share sent conditional on sending & & $26.5 \%$ & $23.9 \%$ & & $98.6 \%$ \\
\hline Number of observations & 392 & 115 & 117 & 219 & 51 \\
\hline Redeeming/accepting the voucher: & Receiver redeemed & & $\overline{\text { Receiver accepted }}$ & Sender redeemec & \\
\hline All subjects & $25.9 \%$ & & $57.1 \%$ & $37.5 \%$ & \\
\hline Round 1 only (1) & $27.1 \%$ & & n.a. & $37.5 \%$ & \\
\hline Rounds 2-4 (2) & $25.3 \%$ & & $57.1 \%$ & n.a. & \\
\hline Number of observations & 143 & & 7 & 24 & \\
\hline $\begin{array}{l}\text { Note: In game } 4 \text {, senders can send up to } 3 \\
\text { is the average amount sent divided by } 35 \text {, } \\
\text { decide whether to accept offers sent by s } \\
\text { round } 1 \text { have the choice of redeeming the } \\
\text { shows the proportion of senders doing sc } \\
\text { vouchers sent. Receiving after round } 1 \text { is } \\
\text { Meticais). 'Receiver sent back' is the pro } \\
\text { by } 35 \text {, the value of the voucher. (1) In rol } \\
\text { at the request of another subject. }\end{array}$ & $\begin{array}{l}5 \text { Meticais to receivers } \\
\text { the value of the vouche } \\
\text { enders. 'Receiver accep } \\
\text { voucher sent by the ex } \\
\text { In this game senders c } \\
\text { automatic. Receivers ca } \\
\text { oortion of receivers sen } \\
\text { ind } 1 \text { the voucher SMS i }\end{array}$ & $\begin{array}{l}\text { 'Sender sent' is t } \\
\text { r. Receiving is aut } \\
\text { ted' is the proport } \\
\text { perimenter by res } \\
\text { an send vouchers } \\
\text { an then send back } \\
\text { ding back positive } \\
\text { s sent at the initia }\end{array}$ & $\begin{array}{l}\text { e proportion of sende } \\
\text { matic in this game. G } \\
\text { on of accepted take-it } \\
\text { onding with a 'yes' SM } \\
\text { o receivers like in the } \\
\text { o senders up to the ful } \\
\text { amounts. The 'share se } \\
\text { ive of the experimente }\end{array}$ & $\begin{array}{l}\text { nding positive am } \\
5 \text { is analogous, ex } \\
\text { eave-it offers. In } \\
\text { our switchboard. ' } \\
\text { game: 'sender ser } \\
\text { ount of the vouche } \\
\text { s the average amol } \\
\text { In rounds 2-4 th }\end{array}$ & $\begin{array}{l}\text { unts. The 'share sent' } \\
\text { cept that receivers } \\
\text { ame } 6 \text {, senders in } \\
\text { Sender redeemed' } \\
\text { t' is the proportion of } \\
r \text { received }(35 \\
\text { int sent back divided } \\
\text { voucher SMS is sent }\end{array}$ \\
\hline
\end{tabular}


Table 6: The decision to redeem the voucher in games $0 / 1 / 2 / 3$

\begin{tabular}{|c|c|c|c|}
\hline & $(1)$ & $(2)$ & (3) \\
\hline \multicolumn{4}{|l|}{ Treatment variables (game 0 is omitted category): } \\
\hline Game 1 dummy (variable cost) & $\begin{array}{c}-0.182 * * \\
(0.073)\end{array}$ & $\begin{array}{c}-0.304 * * * \\
(0.064)\end{array}$ & $\begin{array}{l}-0.134 \\
(0.182)\end{array}$ \\
\hline Game 2 dummy (shaming and fixed cost of sending) & $\begin{array}{c}-0.181 * * \\
(0.084)\end{array}$ & $\begin{array}{c}-0.302 * * * \\
(0.076)\end{array}$ & $\begin{array}{l}-0.119 \\
(0.215)\end{array}$ \\
\hline Game 3 dummy (erroneous message and fixed cost of sending) & $\begin{array}{l}-0.116 \\
(0.096)\end{array}$ & $\begin{array}{c}-0.213 * * \\
(0.094)\end{array}$ & $\begin{array}{c}0.023 \\
(0.200)\end{array}$ \\
\hline Non-anonymous treatment dummy & $\begin{array}{c}-0.208 * * * \\
(0.071)\end{array}$ & $\begin{array}{c}-0.196^{* * *} \\
(0.072)\end{array}$ & $\begin{array}{l}-0.369 * \\
(0.214)\end{array}$ \\
\hline Dummy $=1$ if subject redeemed a voucher in a previous period & & $\begin{array}{c}0.346 * * * \\
(0.090)\end{array}$ & \\
\hline \multicolumn{4}{|c|}{ Pairwise differences in individual characteristics times non-anonymous treatment dummy: } \\
\hline Same gender & & & $\begin{array}{c}0.179 \\
(0.158)\end{array}$ \\
\hline Same post-secondary education dummy & & & $\begin{array}{c}0.082 \\
(0.152)\end{array}$ \\
\hline Absolute difference in age & & & $\begin{array}{c}0.004 \\
(0.007)\end{array}$ \\
\hline Absolute difference in income (in '000 Meticais/month) & & & $\begin{array}{l}-0.009 \\
(0.012)\end{array}$ \\
\hline Round dummies & yes & yes & yes \\
\hline Period dummies & yes & yes & yes \\
\hline Individual characteristics: & no & yes & yes \\
\hline Pairwise differences in individual characteristics (uninteracted): & no & no & yes \\
\hline Intercept & $\begin{array}{c}0.467 * * * \\
(0.094)\end{array}$ & $\begin{array}{c}0.646 * * * \\
(0.128)\end{array}$ & $\begin{array}{c}0.668 * * \\
(0.308)\end{array}$ \\
\hline Adjusted R-squared & 0.017 & 0.153 & 0.028 \\
\hline Number of observations & 258 & 244 & 117 \\
\hline \multicolumn{4}{|l|}{ Joint coefficient tests: } \\
\hline Test that game $1(\beta 1)=$ game $2(\beta 2)$ & 0.992 & 0.984 & 0.885 \\
\hline Test that game $1(\beta 1)=$ game $3(\beta 3)$ & 0.444 & 0.250 & 0.258 \\
\hline Test that game $2(\beta 2)=$ game $3(\beta 3)$ & 0.467 & 0.248 & 0.317 \\
\hline
\end{tabular}

Note: All regressions are OLS. The dependent variable is a binary variable defined as 1 if, when given the chance, the subject sends an SMS accepting the voucher. In column 3 we only include observations from rounds 2-3-4 since, in round 1, all SMS originate from the experimenters and thus differences in individual characteristics are not defined; we also include as controls the pairwise differences in individual characteristics uninteracted with the non-anonymous dummy. Individual characteristics include a female dummy, age, a post-secondary education dummy, and income in Meticais/month. Robust standard errors reported in parenthesis. ${ }^{*}$ significant at $10 \% ; * *$ significant at $5 \% ; * * *$ significant at $1 \%$. 
Table 7: The decision to send the voucher in games $0 / 1 / 2 / 3$

\begin{tabular}{|c|c|c|c|}
\hline & $(1)$ & $(2)$ & $(3)$ \\
\hline \multicolumn{4}{|l|}{ Treatment variables (game 0 is omitted category): } \\
\hline Game 1 dummy (variable cost) & $\begin{array}{c}-0.118 * * \\
(0.056)\end{array}$ & $\begin{array}{c}-0.089 * * \\
(0.042)\end{array}$ & $\begin{array}{c}-0.195 * * \\
(0.086)\end{array}$ \\
\hline Game 2 dummy (shaming and fixed cost of sending) & $\begin{array}{c}-0.174 * * * \\
(0.045)\end{array}$ & $\begin{array}{c}-0.135^{* * *} \\
(0.037)\end{array}$ & $\begin{array}{c}-0.189 * * * \\
(0.045)\end{array}$ \\
\hline Game 3 dummy (erroneous message and fixed cost of sending) & $\begin{array}{c}-0.195 * * * \\
(0.045)\end{array}$ & $\begin{array}{c}-0.187 * * * \\
(0.039)\end{array}$ & $\begin{array}{c}-0.262 * * * \\
(0.080)\end{array}$ \\
\hline Non-anonymous treatment dummy & $\begin{array}{c}-0.075 * * * \\
(0.026)\end{array}$ & $\begin{array}{c}0.023 \\
(0.022)\end{array}$ & $\begin{array}{l}-0.116^{*} \\
(0.062)\end{array}$ \\
\hline Additional cost sending the voucher & $\begin{array}{l}-0.001 \\
(0.005)\end{array}$ & $\begin{array}{c}0.001 \\
(0.004)\end{array}$ & $\begin{array}{c}0.000 \\
(0.005)\end{array}$ \\
\hline Dummy $=1$ if subject redeemed a voucher in the current period & & $\begin{array}{c}0.466 * * * \\
(0.041)\end{array}$ & \\
\hline Dummy $=1$ if subject redeemed a voucher in a previous period & & $\begin{array}{c}0.141 * * * \\
(0.041)\end{array}$ & \\
\hline \multicolumn{4}{|c|}{ Pairwise differences in individual characteristics times non-anonymous treatment dummy: } \\
\hline Same gender & & & $\begin{array}{c}0.044 \\
(0.051)\end{array}$ \\
\hline Same post-secondary education dummy & & & $\begin{array}{c}0.052 \\
(0.051)\end{array}$ \\
\hline Absolute difference in age & & & $\begin{array}{l}-0.000 \\
(0.002)\end{array}$ \\
\hline Absolute difference in income (in '000 Meticais/month) & & & $\begin{array}{l}-0.002 \\
(0.004)\end{array}$ \\
\hline Round dummies & yes & yes & yes \\
\hline Period dummies & yes & yes & yes \\
\hline Individual characteristics & no & yes & yes \\
\hline Pairwise differences in individual characteristics (uninteracted): & no & no & yes \\
\hline Intercept & $\begin{array}{c}0.299 * * * \\
(0.032)\end{array}$ & $\begin{array}{c}0.324 * * * \\
(0.044)\end{array}$ & $\begin{array}{c}0.489 * * * \\
(0.082)\end{array}$ \\
\hline R-squared & 0.042 & 0.389 & 0.128 \\
\hline Number of observations & 806 & 770 & 731 \\
\hline \multicolumn{4}{|l|}{ Joint coefficient tests: } \\
\hline Test that game $1(\beta 1)=$ game $2(\beta 2)$ & 0.156 & 0.138 & 0.109 \\
\hline Test that game $1(\beta 1)=$ game $3(\beta 3)$ & 0.042 & 0.004 & 0.047 \\
\hline Test that game $2(\beta 2)=$ game $3(\beta 3)$ & 0.505 & 0.047 & 0.642 \\
\hline
\end{tabular}

Note: All regressions are OLS. The dependent variable is a binary variable defined as 1 if, when given the chance, the subject sends an SMS giving the voucher to another subject. In game 3, sending the false message (only 2 observations) is assimilated to not sending the voucher. The additional cost of sending the voucher is 0 in game 0 , 5 Meticais in games 2 and 3 , and varying between 0/5/10/15 Meticais in game 1 . There is no sending in round 4 . In column 3, we also include as controls the pairwise differences in individual characteristics uninteracted with the non-anonymous dummy. Individual characteristics include a female dummy, age, a post-secondary education dummy, and income in Meticais/month. Robust standard errors reported in parenthesis. * significant at $10 \% ; * *$ significant at $5 \% ; * * *$ significant at $1 \%$. 
Table 8: The decision to send something in games 4/5/6

\begin{tabular}{|c|c|c|c|}
\hline & & $(1)$ & $(2)$ \\
\hline \multicolumn{4}{|l|}{ Treatment variables (game 4 is omitted category): } \\
\hline \multicolumn{2}{|l|}{ Game 5 dummy (ultimatum) } & $\begin{array}{c}0.053 \\
(0.051)\end{array}$ & $\begin{array}{c}0.048 \\
(0.051)\end{array}$ \\
\hline \multicolumn{2}{|l|}{ Game 6 dummy (reverse dictator -- sender) } & $\begin{array}{c}0.149 * * * \\
(0.047)\end{array}$ & $\begin{array}{c}0.161 * * * \\
(0.049)\end{array}$ \\
\hline \multicolumn{2}{|l|}{ Game 6 dummy (reverse dictator -- receiver) } & $\begin{array}{c}0.066 \\
(0.068)\end{array}$ & $\begin{array}{c}0.073 \\
(0.068)\end{array}$ \\
\hline \multicolumn{2}{|l|}{ Non-anonymous treatment dummy } & $\begin{array}{l}-0.063 * \\
(0.035)\end{array}$ & $\begin{array}{c}0.009 \\
(0.068)\end{array}$ \\
\hline \multicolumn{4}{|c|}{ Pairwise differences in individual characteristics times non-anonymous treatment dummy: } \\
\hline Same gender dummy & & & $\begin{array}{c}0.109 \\
(0.080)\end{array}$ \\
\hline Absolute difference in age & & & $\begin{array}{c}0.001 \\
(0.003)\end{array}$ \\
\hline Absolute difference in income (in '000 Meticais/month) & & & $\begin{array}{l}-0.013 \\
(0.009)\end{array}$ \\
\hline Round dummies & & yes & yes \\
\hline Period dummies & & yes & yes \\
\hline Individual characteristics: & & no & yes \\
\hline Pairwise differences in individual characteristics (uninteracted): & & no & yes \\
\hline Intercept & & $\begin{array}{c}0.204 * * * \\
(0.046)\end{array}$ & $\begin{array}{c}0.437 * * * \\
(0.115)\end{array}$ \\
\hline R-squared & & 0.040 & 0.103 \\
\hline Number of observations & & 502 & 465 \\
\hline \multicolumn{4}{|l|}{ Joint coefficient tests: } \\
\hline Test that game $5(\beta 5)=$ game $6--\operatorname{sender}(\beta 6)$ & p-value & 0.057 & 0.032 \\
\hline Test that game $5(\beta 5)=$ game $6--$ receiver $(\beta 6 b)$ & p-value & 0.849 & 0.645 \\
\hline Test that game 6 sender $(\beta 6)=$ game 6 receiver $(\beta 6 b)$ & p-value & 0.158 & 0.188 \\
\hline
\end{tabular}

Note: All regressions are OLS. The dependent variable is a binary variable defined as 1 if, when given the chance, the subject sends an SMS sharing the voucher with another subject. In column 2 we also include as controls the pairwise differences in individual characteristics uninteracted with the nonanonymous dummy. The absolute difference in education level is omitted due to multicollinearity. Individual characteristics include a female dummy, age, a post-secondary education dummy, and income in Meticais/month. Robust standard errors reported in parenthesis. * significant at 10\%; ** significant at $5 \% ; * * *$ significant at $1 \%$. 
Table 9: Amount sent in games 4/5/6, conditional on sending

(1)

Treatment variables (game 4 is omitted category):

Game 5 dummy (ultimatum)

Game 6 dummy (reverse dictator -- receiver)

Intercept

R-squared

Number of observations

17

Joint coefficient tests:

Test that game $5(\beta 5)=$ game 6 -- receiver $(\beta 6 b)$ p-value

0.000

Note: All regressions are OLS. The dependent variable is the amount sent to another subject in Meticais, conditional on an amount being sent. This decision is only relevant in game 4 (sender), game 5 (sender), and game 6 (receiver). Due to the small number of observations, other regressors are not included. Robust standard errors reported in parenthesis. * significant at 10\%; ** significant at $5 \% ; * *$ significant at $1 \%$. 


\section{Table 10: The decisions to redeem and send in games $0 / 1 / 2 / 3$ without inactive subjects}

\begin{tabular}{|c|c|c|c|}
\hline & & $\begin{array}{c}\text { Redeem } \\
\text { (1) } \\
\end{array}$ & $\begin{array}{l}\text { Send } \\
(2)\end{array}$ \\
\hline \multicolumn{4}{|l|}{ Treatment variables (game 0 is omitted category): } \\
\hline \multicolumn{2}{|l|}{ Game 1 dummy (variable cost) } & $\begin{array}{c}-0.605^{* * *} \\
(0.198)\end{array}$ & $\begin{array}{c}-0.328 * * * \\
(0.107)\end{array}$ \\
\hline \multicolumn{2}{|l|}{ Game 2 dummy (shaming and fixed cost of sending) } & $\begin{array}{c}-0.586^{* * *} \\
(0.182)\end{array}$ & $\begin{array}{c}-0.447 * * * \\
(0.086)\end{array}$ \\
\hline \multicolumn{2}{|l|}{ Game 3 dummy (erroneous message and fixed cost of sending) } & $\begin{array}{l}-0.384 \\
(0.248)\end{array}$ & $\begin{array}{c}-0.525 * * * \\
(0.083)\end{array}$ \\
\hline \multicolumn{2}{|l|}{ Non-anonymous treatment dummy } & $\begin{array}{c}-0.383^{* * *} \\
(0.144)\end{array}$ & $\begin{array}{c}0.043 \\
(0.056)\end{array}$ \\
\hline \multicolumn{2}{|l|}{ Additional cost sending the voucher } & & $\begin{array}{c}0.003 \\
(0.009)\end{array}$ \\
\hline \multicolumn{2}{|l|}{ Dummy $=1$ if subject redeemed a voucher in the current period } & & $\begin{array}{c}0.331 * * * \\
(0.050)\end{array}$ \\
\hline \multicolumn{2}{|l|}{ Dummy $=1$ if subject redeemed a voucher in a previous period } & $\begin{array}{l}0.268^{*} \\
(0.157)\end{array}$ & $\begin{array}{c}0.310^{* * *} \\
(0.066)\end{array}$ \\
\hline Round dummies: & & yes & yes \\
\hline Period dummies: & & yes & yes \\
\hline Individual characteristics: & & yes & yes \\
\hline Intercept & & $\begin{array}{c}1.206 * * * \\
(0.241)\end{array}$ & $\begin{array}{c}0.686^{* * *} \\
(0.100)\end{array}$ \\
\hline R-squared & & 0.121 & 0.314 \\
\hline Number of observations & & 107 & 337 \\
\hline \multicolumn{4}{|l|}{ Joint coefficient tests: } \\
\hline Test that game $1(\beta 1)=$ game $2(\beta 2)$ & p-value & 0.899 & 0.078 \\
\hline Test that game $1(\beta 1)=$ game $3(\beta 3)$ & p-value & 0.206 & 0.010 \\
\hline Test that game $2(\beta 2)=$ game $3(\beta 3)$ & p-value & 0.192 & 0.179 \\
\hline
\end{tabular}

Note: All regressions are OLS. In redeem the voucher, the dependent variable is a binary variable defined as 1 if, when given the chance, the subject sends an SMS accepting the voucher. In send the voucher, the dependent variable is a binary variable defined as 1 if, when given the chance, the subject sends an SMS giving the voucher to another subject. In game 3, sending the false message (only 2 observations) is assimilated to not sending the voucher. The additional cost of sending the voucher is 0 in game 0,5 Meticais in games 2 and 3, and varying between 0/5/10/15 Meticais in game 1. Individual characteristics include gender, age, a post-secondary education dummy, and monthly income. Robust standard errors reported in parenthesis. $*$ significant at $10 \% ; * *$ significant at $5 \% ; * *$ significant at $1 \%$. 
Table 11: The decision to send airtime in games 4-5-6 without inactive subjects

\begin{tabular}{|c|c|c|}
\hline & & $\begin{array}{c}\text { send any } \\
\text { amount }\end{array}$ \\
\hline \multicolumn{3}{|l|}{ Treatment variables (game 4 is omitted category): } \\
\hline Game 5 dummy (ultimatum) & & $\begin{array}{c}0.073 \\
(0.081)\end{array}$ \\
\hline Game 6 dummy (reverse dictator -- sender) & & $\begin{array}{c}0.346^{* * *} \\
(0.076)\end{array}$ \\
\hline Game 6 dummy (reverse dictator -- receiver) & & $\begin{array}{c}0.262 * * \\
(0.132)\end{array}$ \\
\hline Non-anonymous treatment dummy & & $\begin{array}{l}-0.027 \\
(0.068)\end{array}$ \\
\hline Round dummies: & & yes \\
\hline Period dummies: & & yes \\
\hline Individual characteristics: & & yes \\
\hline Intercept & & $\begin{array}{l}0.258^{*} \\
(0.141)\end{array}$ \\
\hline R-squared & & 0.116 \\
\hline Number of observations & & 245 \\
\hline \multicolumn{3}{|l|}{ Joint coefficient tests: } \\
\hline Test that game $5(\beta 5)=$ game $6--\operatorname{sender}(\beta 6)$ & p-value & 0.001 \\
\hline Test that game $5(\beta 5)=$ game $6--$ receiver $(\beta 6 b)$ & $p$-value & 0.176 \\
\hline Test that game 6 sender $(\beta 6)=$ game 6 receiver $(\beta 6 b)$ & $\underline{p \text {-value }}$ & 0.481 \\
\hline
\end{tabular}

Note: All regressions are OLS. The dependent variable is a binary variable defined as 1 if, when given the chance, the subject sends an SMS sharing the voucher with another subject. Individual characteristics include gender, age, a post-secondary education dummy, and monthly income. Robust standard errors reported in parenthesis. ${ }^{*}$ significant at 10\%; ${ }^{* *}$ significant at 5\%; *** significant at $1 \%$. 


\section{Appendix}

Table A1: Introductory messages

\begin{tabular}{|c|c|c|c|c|}
\hline \multirow[t]{2}{*}{ Version } & \multirow[t]{2}{*}{ Language } & \multicolumn{3}{|c|}{ Introductory messages } \\
\hline & & & All subjects/days & \\
\hline \multirow{2}{*}{$\begin{array}{l}\text { Anonymous } \\
\text { and non- } \\
\text { anonymous }\end{array}$} & $\begin{array}{l}\text { Original } \\
\text { Portuguese }\end{array}$ & $\begin{array}{l}\text { Msg d project mKesh NOVAFRICA. Enviaremos } \\
\text { sms em breve. Respond pra ganhar bonus mKesh. } \\
\text { Respond a cada numero que lhe enviar SMS. Duvidas } \\
\text { ligue ou SMS- } 821783387\end{array}$ & $\begin{array}{l}\text { NOVAFRICA. Nossas SMS NAO SAO ENVIADAS } \\
\text { por } 823131 \text {. SAO ENVIADAS por varios } \\
\text { NUMEROS NORMAIS. Respond a cada numero. So } \\
\text { custa SMS ou } 2 \text { meticais quando nao tem SMS }\end{array}$ & $\begin{array}{l}\text { Senhor(a) fez parte do estudo mKesh. Daremos } \\
\text { oportunidade de ganhar dinheiro em mKesh. No fim } \\
\text { tera um bonus por participar de } 70 \mathrm{Mts} \text {. Responder } \\
\text { custa } 1 \mathrm{sms} \text { ou } 2 \mathrm{Mts}\end{array}$ \\
\hline & $\begin{array}{l}\text { English } \\
\text { translation }\end{array}$ & $\begin{array}{l}\text { Message from project mKesh NOVAFRICA. We } \\
\text { will soon send SMS. Answer to earn bonus mKesh. } \\
\text { Answer to each number sending SMS. Any doubts } \\
\text { call or send SMS to } 821783387 \text {. }\end{array}$ & $\begin{array}{l}\text { NOVAFRICA. Our SMS ARE NOT SENT through } \\
823131 \text {. They ARE SENT through several } \\
\text { REGULAR NUMBERS. Answer to each of those } \\
\text { numbers. It only costs SMS or } 2 \text { Meticais when you } \\
\text { do not have SMS. }\end{array}$ & $\begin{array}{l}\text { You took part in the mKesh study. We will give you } \\
\text { the opportunity to earn money in mKesh. In the end } \\
\text { you will have a bonus of } 70 \text { Meticais for } \\
\text { participating. Responding costs } 1 \text { SMS or } 2 \\
\text { Meticais. }\end{array}$ \\
\hline
\end{tabular}




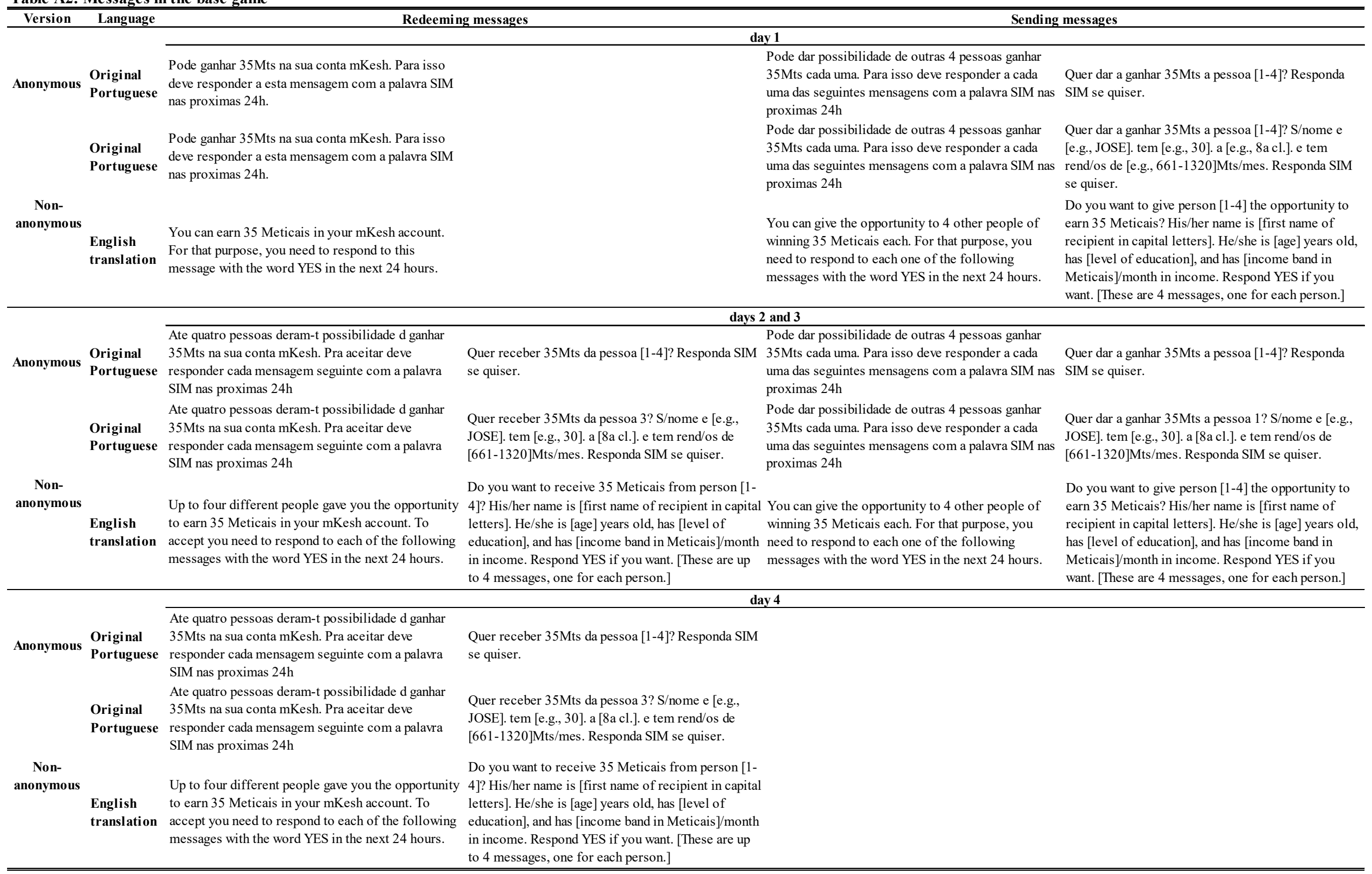


Pode ganhar 35Mts na sua conta mKesh. Para isso

Original Pode ganhar 35Mts na sua conta mKesh. Para isso

mensagem com a palavra SIM nas proximas $24 \mathrm{~h}$.

Original Pode ganhar 35Mts na sua conta mKesh. Para isso

Portuguese deve responder a esta mensagem com a palavra SIM nas proximas $24 \mathrm{~h}$

Non-

anonymous

English You can earn 35 Meticais in your mKesh account.

English For that purpose, you need to respond to this

message with the word YES in the next 24 hours.

Pode dar possibilidade de outras 4 pessoas ganhar

35Mts cada uma. Para isso deve responder a cada Quer dar a ganhar 35 Mts a pessoa [1-4]? Se quiser uma das seguintes mensagens com a palavra SIM nas responda SIM. O custo sera [0/5/10/15]Mts em proximas $24 \mathrm{~h}$. Pode tambem ter de pagar uma conta mKesh.

comissao.

Pode dar possibilidade de outras 4 pessoas ganhar Quer dar a ganhar 35 Mts a pessoa [1-4]? S/nome e P5Mts PrMts cada una. Para isso deve responder a cad proximas $24 \mathrm{~h}$. Pode tambem ter de pagar uma comissao.

You can give the opportunity to 4 other people of winning 35 Meticais each. For that purpose, yo need to respond to each one of the following messages with the word YES in the next 24 hours. You may also have to pay a fee.

\section{days 2 an 3}

\section{Ate quatro pessoas enviaram-lhe a possibilidade de}

Pode dar possibilidade de outras 4 pessoas ganhar

Original ganhar 35 Mts na sua conta mKesh. Para aceitar deve Quer receber 35Mts da pessoa [1-4]? Responda SIM

Portuguese responder a cada uma das seguintes mensagens com se quiser. a palavra SIM nas proximas $24 \mathrm{~h}$.

Ate quatro pessoas enviaram-lhe a possibilidade de

Original ganhar 35 Mts na sua conta mKesh. Para aceitar deve Quer receber 35Mts da pessoa 3? S/nome e [e.g.,

Portuguese responder a cada uma das seguintes mensagens com a palavra SIM nas proximas $24 \mathrm{~h}$ [661-1320]Mts/mes. Responda SIM se quiser. a. Para isso deve responder a cad uma das seguintes mensagens com a palavra SIM comissao

Pode dar possibilidade de outras 4 pessoas ganha $35 \mathrm{Mts}$ cada uma. Para isso deve responder a cad uma das seguintes mensagens com a palavra SIM $n$ proximas $24 \mathrm{~h}$. Pode tambem ter de pagar uma comissao.

NonUp to four different people gave you the opportunity 4 (d) English to to four different people gave you the opportunicais in your mKesh account. To

Do you want to receive 35 Meticais from person [1translation accept you need to respond to each of the following
messages with the word YES in the next 24 hours. letters]. $\mathrm{He} / \mathrm{she}$ is [age] years old, has [level of

You can give the opportunity to 4 other people of winning 35 Meticais each. For that purpose, you

], and has [income band in Meticais] $/$ mon need to respond to each one of the following messages with the word YES in the next 24 hours. You may also have to pay a fee.

day 4

Ate quatro pessoas enviarm-lhe a possibilidede de

Original ganhar 35 Mts na sua conta mKesh. Para aceitar deve Quer receber 35Mts da pessoa [1-4]? Responda SIM

Portuguese responder a cada uma das seguintes mensagens com se quiser.

a palavra SIM nas proximas $24 \mathrm{~h}$.

Ate quatro pessoas enviaram-lhe a possibilidade de

Original ganhar $35 \mathrm{Mts}$ na sua conta mKesh. Para aceitar deve Quer receber 35Mts da pessoa 3? S/nome e [e.g.

Portuguese responder a cada uma das seguintes mensagens com JOSE].tem [e.g., 30]. a [8a cl.]. e tem rend/os

Non-

anonymous
English
translation a palavra SIM nas proximas $24 \mathrm{~h}$.

Up to four differet people gave yours on [1-

Up to four different people gave you the opportunity 4]? His/her name is [first name of recipient in capit to earn 35 Meticais in your mKesh account. To letters]. He/she is [age] years old, has [level of

accept you need to respond to each of the following education], and has [income band in Meticais] $/$ month
messages with the word YES in the next 24 hours. in income. Respond YES if you want. [These are up
Quer dar a ganhar 35 Mts a pessoa [1-4]? S/nome
[e.g., JOSE]. tem [e.g., 30]. a [e.g.,. 8a cl.] e tem

[e.g., JOSE]. tem [e.g., 30]. a [e.g., 8a cl.]. e tem
rend/os de [e.g., 661-1320]Mts/mes. Se quiser rend/os de [e.g., $661-1320] \mathrm{Mts} / \mathrm{mes}$. Se quiser
responda SIM. O custo sera [0/5/10/15]Mts em responda SIM.
conta mKes

Do you want to give person [1-4] the opportunity to earn 35 Meticais? His/her name is [first name of

recipient in capital letters]. He/she is [age] years old, has [level of education], and has [income band in Metic $]$ / Meticais] mKesh account. [These are 4 messages, one for each person, with random price between the four levels.]

Quer dar a ganhar $35 \mathrm{Mts}$ a pessoa [1-4]? Se quiser responda SIM. O custo sera [0/5/10/15]Mts em conta mKesh.

Quer dar a ganhar $35 \mathrm{Mts}$ a pessoa [1-4]? S/nome e [e.g., JOSE]. tem [e.g., 30]. a [e.g., 8a cl.]. e tem rend/os de [e.g., 661-1320]Mts/mes. Se quiser responda SIM. O custo sera [0/5/10/15]Mts em conta mKesh.

Do you want to give person [1-4] the opportunity to earn 35 Meticais? His/her name is [first name of recipient in capital letters]. He/she is [age] years old has [level of education], and has [income band in Meticais]/month in income Respond YES if you want. The cost will be $[0 / 5 / 10 / 15]$ Meticais yo mKesh accos \begin{tabular}{l} 
person, with random price between the four levels.] \\
\hline
\end{tabular} 
Anonymous Original Pode ganhar 35Mts na sua conta mKesh. Para isso

Portuguese deve responder a esta mensagem com a palavra SIM nas proximas $24 \mathrm{~h}$

Original Pode ganhar 35Mts na sua conta mKesh. Para isso

Portuguese deve responder actan nas proximas $24 \mathrm{~h}$

Non-

nonymous

English You can earn 35 Meticais in your mKesh account.

For that purpose, you need to respond to this

message with the word YES in the next 24 hours.

Pode dar possibilidade de outras 4 pessoas ganhar

35Mts cada uma. Para isso deve responder a cad


proximas $24 \mathrm{~h}$. Pode tambem ter de pagar um comissao.

Pode dar possibilidade de outras 4 pessoas ganhar 35Mts cada uma. Para isso deve responder a cada uma das seguintes mensagens com a palavra SIM
proximas $24 \mathrm{~h}$. Pode tambem ter de pagar uma

You can give the opportunity to 4 other people of winning 35 Meticais each. For that purpose, you need to respond to each one of the following messages with the word YES in the next 24 hour. You may also have to pay a fee.

\section{days 2 and 3}

Ate quatro pessoas enviaram-lhe a possibilidade de

Original ganhar 35 Mts na sua conta mKesh. Para aceitar deve

Portuguese responder a cada uma das seguintes mensagens con a palavra SIM nas proximas $24 \mathrm{~h}$ Quer receber 35Mts da pessoa [1-4]? Responda SIM 35Mts cada uma. Para isso deve responder a cada

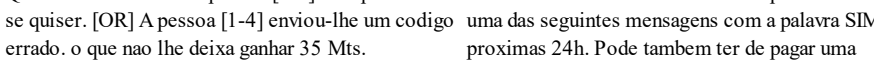
comissao.

Quer receber 35Mts da pessoa 3? S/nome e [e.g., JOSE]. tem [e.g., 30]. a [8a cl.]. e tem rend/os de

Ate quatro pessoas enviaram-lhe a possibilidade de

Original ganhar $35 \mathrm{Mts}$ na sua conta mKesh. Para aceitar deve

Portuguese responder a cada uma das seguintes mensagens cont a palavra SIM nas proximas 24

Non[661-1320]Mts/mes. Responda SIM se quiser. [OR] 35Mts cada umal Pade de outras 4 pessoas ganh A pessoa [1-4] enviou-lhe um codigo errado. [OR] 35Mts cada uma. Para isso deve responder a cad nao lhe deixa ganhar $35 \mathrm{Mts}$. S/nome e [e.g., JOSE]. proximas $24 \mathrm{~h}$. Pode tambem ter de pagar uma tem [e.g., 30]. a [8a cl.]. e tem rend/os de [661- comissao. $1320] \mathrm{Mts} / \mathrm{mes}$.

Do you want to receive 35 Meticais from person [14]? His/her name is [first name of recipient in capit

letters]. He/she is [age] years old, has [level of
Up to four different people gave you the opportunity education], and has [income band in Meticais $/$ month Up to four different people gave you the opportunity education], and has [income band in Meticais] month winning 35 Meticais each. For that purpose, you English to earn 35 Meticais in your mKesh account. To

accept you need to respond to each of the following income. Respond YES if you want. [OR] Person [1- need to respond to each one of the following

3is. 35 Meticais. His/her name is [first name of recipient
Mou may also have to pay a fee.

in capital letters]. He/she is [age] years old, h level of eduction], and has [income band in

Ate quatro pessoas enviaram-lhe a possibilidade $d$

mKesh. Para aceitar deve Quer receber 35Mts da pessoa [1-4]? Responda SIM a palavra SIM nas proximas 24

ce 0 que nao the deixa ganhar $35 \mathrm{Mt}$.

Quer receber 35Mts da pessoa 3? S/nome e [e.g. Ate quatro pessoas enviaram-lhe a possibilidade de JOSE]. tem [e.g., 30]. a [8a cl.]. e tem rend/os de

Original ganhar $35 \mathrm{Mts}$ na sua conta mKesh. Para aceitar deve $[661-1320] \mathrm{Mts} / \mathrm{mes}$. Responda SIM se quiser. [OR]

Portuguese responder a cada uma das seguintes mensagens com Ano lhe deixa ganhar 35 Mts codigo errado. o que a palavia SIM nas proximas $24 \mathrm{~h}$

Non-

anonymous

English

Up to four different people gave you the opportun accept you need to respond to each of the following messages with the word YES in the next 24 hours. tem [e.g., 30]. a [8a cl.]. e tem rend/os de [661-

tem [e.g., 30]. a
$1320] \mathrm{Mts} / \mathrm{mes}$.

Do you want to receive 35 Meticais from person [14]? His/her name is [first name of recipient in capit letters]. He/she is [age] years old, has [level of

education], and has [income band in Meticais]/month in income. Respond YES if you want. [OR] Person [1] sent you a wrong code, which does not let you win

35 Meticais. His/her name is [first name of recipie

in capital letters]. He/she is [age] years old, has

[level of education], and has [income band in alternativa enviaremos um codigo errado a pesso

Quer dar a ganhar 35 Mts a pessoa [1-4]? S/nome e [e.g., JOSE]. tem [e.g., 30]. a [e.g., 8 a cl.]. e ter rend/os de [e.g., 661-1320]Mts/mes. Se quise resp/a SIM. O custo sera 5 Mts em mKesh. Em alternativa enviaremos um codigo errado a pessoa. Do you want to give person [1-4] the opportunity to earn 35 Meticais? His/her name is [first name of recipient in capital letters]. He/she is [age] years old has [level of education], and has [income band in Meticais] month in income. Respond YES if you want. The cost will be 5 Meticais in the mKesh account. [These are 4 messages, one for each person.]

Quer dar a ganhar 35Mts a pessoa [1-4]? Se quise esp/a SIM. O custo sera $5 \mathrm{Mts}$ em mKesh. Em alternativa enviaremos um codigo errado a pessoa

Quer dar a ganhar 35 Mts a pessoa [1-4]? S/nome [e.g., JOSE]. tem [e.g., 30]. a [e.g., 8a cl.]. e tem rend/os de [e.g., 661-1320]Mts/mes. Se quise resp/a SIM. O custo sera 5Mts em mKesh. Em alternativa enviaremos um codigo errado a pessoa

Do you want to give person [1-4] the opportunity to earn 35 Meticais? His/her name is [first name of recipient in capital letters]. He/she is [age] years old, has [level of education], and has [income band in Meticais $] /$ month in income. Respond YES if you want. The cost will be 5 Meticais in the mKes account. [These are 4 messages, one for each person.]

Meticais $\mathrm{m}$ month in income. 
Original Pode ganhar $35 \mathrm{Mts}$ na sua conta mKesh. Para isso

Original Pode ganhar 35Mts na sua conta mKesh. Para isso Portuguese deve responder a esta mensagem com a palavra SIM

Non-

You can earn 35 Meticais in your mKesh account.

English For that purpose, you need to respond to this

message with the word YES in the next 24 hou
Pode dar possibilidade de outras 4 pessoas ganhar 35Mts cada uma. Para isso deve responder a cad uma das seguintes mensagens com a palavra SIM proximas $24 h$. Pode tambem ter de pagar uma

Pode dar possibilidade de outras 4 pessoas ganha 35Mts cada uma. Para isso deve responder a cad uma das seguintes mensagens com a palaura SIM proximas $24 \mathrm{~h}$. Pode tambem ter de pagar un You can give the opportunity to 4 other people of need to respond to each one of the following You may also have to pay a fe.

\section{days 2 and 3}

Ate quatro pessoas enviaram-lhe a possibilidade

$\begin{array}{lll}\text { Ate quatro pessoas enviaram-lhe a possibilidade de } & \text { Quer receber 35Mts da pessoa [1-4]? Responda SIM } \\ \text { Original } & \text { ganhar } 35 \mathrm{Mts} \text { na sua conta mKesh. Para aceitar deve } & \text { se quiser. [OR] A pessoa [1-4] enviou-lhe um codigo }\end{array}$ a palavra SIM nas proximas $24 \mathrm{~h}$. errado. o que nao lhe deixa ganhar $35 \mathrm{Mt}$

Quer receber $35 \mathrm{Mts}$ da pessoa 3 ? S nome e $[$ e.g, Ate quatro pessoas enviaram-lhe a possibilidade $\mathrm{d}$

Original ganhar $35 \mathrm{Mts}$ na sua conta mKesh. Para aceitar deve

Portuguese res a palavra SIM nas proximas $24 \mathrm{~h}$. SEE]. tem [e.g., 30]. a [8a cl.]. e tem rend/os de

[661-1320]Mts/mes. Responda SIM se quiser. [OR]

A pessoa [1-4] enviou-lhe um codigo errado. o que
nao lhe deixa ganhar $35 \mathrm{Mts}$. S/nome e [e.g., JOSE]. tem [e.g., 30]. a [8a cl.]. e tem rend/os de [661$320] \mathrm{Mts} / \mathrm{mes}$

Dou want to receive 35 Meticais from person [1-

? His/her name is [first name of recipient in capita

etters]. He/she is [age] years old, has [level of

education], and has [income band in Meticais $/$ month You can give the opportunity to 4 other people of

Up to four different people gave you the opport English to earn $35 \mathrm{M}$ messages with the word YES in the next 24 hours. income. Respond YES if you want. [OR] Person [1- winning 35 Meticais each. For that purpose, you sent you a wrong code, which does not let you win need to respond to each one of the following

in capital letters]. He/she is [age] years old, has You may also have to pay a fec.

[level of education], and has [income band in

These are up to 4 essages, one for each person.

Ate quatro pessoas enviaram-lhe a possibilidade de Quer receber 35 Mts da pessoa [1-4]? Responda SIM

Original ganhar 35 Mts na sua conta mKesh. Para aceitar deve se quiser. [OR] A pessoa [1-4] enviou-lhe um codigo $\begin{aligned} & \text { Portuguese responder a cada uma das seguintes mensagens com } \\ & \text { a palavra SIM nas proximas } 24 \mathrm{~h} .\end{aligned}$
errado. o que nao lhe deixa ganhar $35 \mathrm{Mts}$.

Quer receber 35Mts da pessoa 3? S/nome e [e.g. Ate quatro pessoas enviaram-lhe a possibilidade de JOSE].tem [e.g., 30]. a [8a cl.]. e tem rend/os de

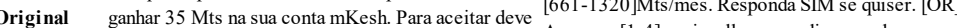

Portuguese responder a cada uma das seguintes mensagens com A pessoa [1-4] enviou-lhe um codigo errado. o que a palavra SIM nas proximas $24 \mathrm{~h}$

Non$m$ [e de $[661$ $320] \mathrm{Mts} / \mathrm{mes}$

Do you want to receive 35 Meticais from person [14]? His/her name is [first name of recipient in capita .

in income. Respond YES if you want [OR] Pesonth

$4]$ sent you a wrong code, which does not let you win

35 Meticais. His/her name is [first name of recipien

in capital letters]. He/she is [age] years old, has

[level of education], and has [income band in

Meticais $/$ month in income. [These are up to 4

English to earn 35 Meticais in your mKesh account. To messages with the word YES in the next 24 hours.
Q dar a ganhar 35Mts a pessoa [1-4]? Se quis

altern/as: enviarmos codigo errado -resp/a NAO.

enviarmos nada -nao resp/a.

Quer dar a ganhar $35 \mathrm{Mts}$ a pessoa [1-4]? S/nome

e.g., JOSE]. tem [e.g., 30]. a [e.g., 8a cl.]. e te

resp/a SIM. O custo sera 5Mts em mKesh. 2

altern/as: enviarmos codigo errado -resp/a NAO. enviarmos nada -nao resp/a.

Do you want to give person $[1-4]$ the opportunity to earn 35 Meticais? His/her name is [first name of

recipient in capital letters]. He/she is [age] years old

has [level of education, and has [income band in

Meticais/month in income. Respond YES if you

want. The cost will be 5 Meticais in the mKes

account. 2 alternatives: we send a wrong code -

respond. [These are 4 messegs, one for each person.

Quer dar a ganhar 35Mts a pessoa [1-4]? Se quis esp/a SIM. O custo sera 5 Mts em mKesh. 2 列

Quer dar a ganhar 35 Mts a pessoa [1-4]? S/nome [e.g., JOSE]. tem [e.g., 30]. a [e.g., 8a cl.]. e tem rend/os de [e.g., 661-1320]Mts/mes. Se quiser
resp/a SIM. O custo sera 5Mts em mKesh. 2 altern/as: enviarmos codigo errado -resp/a NAO. enviarmos nada -nao resp/a.

Do you want to give person $[1-4]$ the opportunity to earn 35 Meticais? His/her name is [first name of ecipient in capital letters]. He/she is [age] years old has [level of education, and has [income band in Meticais. account 2 alternatives: we send a wrong code respond NO; we do not send anything - do not respond. [These are 4 messages, one for each person.] messages, one for each person 


\begin{tabular}{|c|c|c|c|c|}
\hline Version & Language & \multicolumn{2}{|c|}{ Redeeming messages } & Sending messages \\
\hline \multirow[b]{2}{*}{ Anonymous } & \multirow[b]{2}{*}{$\begin{array}{l}\text { Original } \\
\text { Portuguese }\end{array}$} & \multicolumn{3}{|c|}{ day 1} \\
\hline & & & & $\begin{array}{l}\text { Ganhou } 35 \mathrm{Mts} \text { em mKesh. Deste valor pode dar ate } 35 \mathrm{Mts} \text { a pessoa [1-4]. Resp/a valor que quer dar } \\
\text { p/este n/o em } 24 \mathrm{~h} \text {. A dif/a p/os } 35 \text { caira na s/ conta mKesh. }\end{array}$ \\
\hline \multirow[b]{2}{*}{$\begin{array}{l}\text { Non- } \\
\text { anonymous }\end{array}$} & $\begin{array}{l}\text { Original } \\
\text { Portuguese }\end{array}$ & & & $\begin{array}{l}\text { Ganhou 35Mts em mKesh. Deste valor pode dar ate 35Mts a pessoa 1. S/nome e [e.g., JOSE]. tem [e.g., } \\
\text { 30]. a [e.g., } 8 \text { a cl.]. e tem rend/os de [e.g., } 661-1320 \text { ] Mts/mes. Resp/a valor que quer dar p/este n/o em } \\
\text { 24h. A dif/a p/os } 35 \text { caira na s/ conta mKesh. }\end{array}$ \\
\hline & $\begin{array}{l}\text { English } \\
\text { translation }\end{array}$ & & & $\begin{array}{l}\text { You have earned } 35 \text { Meticais in your mKesh account. From this value you can give up to } 35 \text { Meticais to } \\
\text { person [1-4]. He/she is [age] years old, has [level of education], and has [income band in Meticais]/month } \\
\text { in income. Respond with the value you want to give to this phone number in the next } 24 \text { hours. The } \\
\text { difference to the } 35 \text { Meticais will be in your mKesh account. [These are } 4 \text { messages, one for each } \\
\text { person.] }\end{array}$ \\
\hline \multirow{3}{*}{ Anonymous } & & \multicolumn{3}{|c|}{ days 2 and 3} \\
\hline & $\begin{array}{l}\text { Original } \\
\text { Portuguese }\end{array}$ & $\begin{array}{l}\text { Ate quatro pessoas enviaram-lhe algum dinheiro para } \\
\text { a sua conta mKesh. }\end{array}$ & Recebeu [up to 35]Mts da pessoa [1-4]. & $\begin{array}{l}\text { Ganhou } 35 \mathrm{Mts} \text { em mKesh. Deste valor pode dar ate } 35 \mathrm{Mts} \text { a pessoa [1-4]. Resp/a valor que quer dar } \\
\text { p/este n/o em } 24 \mathrm{~h} \text {. A dif/a p/os } 35 \text { caira na s/ conta mKesh. }\end{array}$ \\
\hline & $\begin{array}{l}\text { Original } \\
\text { Portuguese }\end{array}$ & $\begin{array}{l}\text { Ate quatro pessoas enviaram-lhe algum dinheiro para } \\
\text { a sua conta mKesh. }\end{array}$ & $\begin{array}{l}\text { Recebeu [up to } 35] \text { Mts da pessoa [1-4]. S/nome e } \\
\text { [e.g., JOSE]. tem [e.g., 30]. a [8a cl.]. e tem rend/os } \\
\text { de [661-1320]Mts/mes. }\end{array}$ & $\begin{array}{l}\text { Ganhou } 35 \mathrm{Mts} \text { em mKesh. Deste valor pode dar ate } 35 \mathrm{Mts} \text { a pessoa } 1 \text {. S/nome e [e.g., JOSE] tem [e.g., } \\
\text { 30]. a [e.g., } 8 \text { a cl.]. e tem rend/os de [e.g., } 661-1320 \text { ] Mts/mes. Resp/a valor que quer dar p/este n/o em } \\
\text { 24h. A dif/a p/os } 35 \text { caira na s/ conta mKesh. }\end{array}$ \\
\hline \multirow[t]{2}{*}{$\begin{array}{c}\text { Non- } \\
\text { anonymous }\end{array}$} & $\begin{array}{l}\text { English } \\
\text { translation }\end{array}$ & $\begin{array}{l}\text { Up to four different people sent you some money to } \\
\text { your mKesh account. }\end{array}$ & $\begin{array}{l}\text { You have received [up to } 35] \text { Meticais from person } \\
\text { [1-4]. His/her name is [first name of recipient in } \\
\text { capital letters]. He/she is [age] years old, has [level } \\
\text { of education], and has [income band in } \\
\text { Meticais]/month in income. [These are up to } 4 \\
\text { messages, one for each person.] }\end{array}$ & $\begin{array}{l}\text { You have earned } 35 \text { Meticais in your mKesh account. From this value you can give up to } 35 \text { Meticais to } \\
\text { person [1-4]. He/she is [age] years old, has [level of education], and has [income band in Meticais]/month } \\
\text { in income. Respond with the value you want to give to this phone number in the next } 24 \text { hours. The } \\
\text { difference to the } 35 \text { Meticais will be in your mKesh account. [These are } 4 \text { messages, one for each } \\
\text { person.] }\end{array}$ \\
\hline & & \multicolumn{3}{|c|}{ 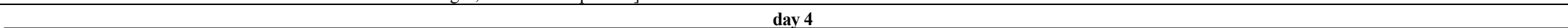 } \\
\hline \multirow[t]{2}{*}{ Anonymous } & $\begin{array}{l}\text { Original } \\
\text { Portuguese }\end{array}$ & $\begin{array}{l}\text { Ate quatro pessoas enviaram-lhe algum dinheiro para } \\
\text { a sua conta mKesh. }\end{array}$ & Recebeu [up to 35]Mts da pessoa [1-4]. & \\
\hline & $\begin{array}{l}\text { Original } \\
\text { Portuguese }\end{array}$ & $\begin{array}{l}\text { Ate quatro pessoas enviaram-lhe algum dinheiro para } \\
\text { a sua conta mKesh. }\end{array}$ & $\begin{array}{l}\text { Recebeu [up to } 35] \text { Mts da pessoa [1-4]. S/nome e } \\
\text { [e.g., JOSE]. tem [e.g., 30]. a [8a cl.]. e tem rend/os } \\
\text { de [661-1320]Mts/mes. }\end{array}$ & \\
\hline $\begin{array}{l}\text { Non- } \\
\text { anonymous }\end{array}$ & $\begin{array}{l}\text { English } \\
\text { translation }\end{array}$ & $\begin{array}{l}\text { Up to four different people sent you some money to } \\
\text { your mKesh account. }\end{array}$ & $\begin{array}{l}\text { You have received [up to } 35] \text { Meticais from person } \\
{[1-4] . \text { His/her name is [first name of recipient in }} \\
\text { capital letters]. He/she is [age] years old, has [level } \\
\text { of education], and has [income band in } \\
\text { Meticais]/month in income. [These are up to } 4 \\
\text { messages, one for each person.] }\end{array}$ & \\
\hline
\end{tabular}




\begin{tabular}{|c|c|c|c|c|}
\hline Version & Language & \multicolumn{2}{|c|}{ Redeeming messages } & Sending messages \\
\hline \multirow[b]{2}{*}{ Anonymous } & \multirow[b]{2}{*}{$\begin{array}{l}\text { Original } \\
\text { Portuguese }\end{array}$} & \multicolumn{3}{|c|}{ day 1} \\
\hline & & & & $\begin{array}{l}\text { Pode ganhar com outra pessoa 35Mts em mKesh. Proponha } \mathrm{q} / \text { tos Mts de } 35 \text { devem ir p/pessoa 1: se ela } \\
\text { aceitar. ambos recebem prop/a. senao nada. Resp/a n/o de } 0-35 \mathrm{em} 24 \mathrm{~h} \text {. }\end{array}$ \\
\hline \multirow[b]{2}{*}{$\begin{array}{l}\text { Non- } \\
\text { anonymous }\end{array}$} & $\begin{array}{l}\text { Original } \\
\text { Portuguese }\end{array}$ & & & $\begin{array}{l}\text { Pode ganhar com outra pessoa } 35 \mathrm{Mts} \text { em mKesh. Proponha q/tos Mts de } 35 \text { devem ir p/pessoa 1: se ela } \\
\text { aceitar. ambos recebem prop/a. senao nada. S/nome e [e.g., JOSE]. tem [e.g., 30]. a [e.g., } 8 \text { a cl.]. e tem } \\
\text { rend/os de [e.g., } 661-1320] \text { Mts/mes. Resp/a n/o de 0-35 em } 24 \mathrm{~h} \text {. }\end{array}$ \\
\hline & $\begin{array}{l}\text { English } \\
\text { translation }\end{array}$ & & & $\begin{array}{l}\text { You can earn } 35 \text { Meticais in mKesh together with another person. Propose how many Meticais out of } 35 \\
\text { should de given to person [1-4]: if he/she accepts, you both earn the amounts you propose; if he/she does } \\
\text { not accept, nobody earns any money. He/she is [age] years old, has [level of education], and has [income } \\
\text { band in Meticais]/month in income. Respond with the value between } 0 \text { and } 35 \text { Meticais in the next } 24 \\
\text { hours. [These are } 4 \text { messages, one for each person.] }\end{array}$ \\
\hline & & \multicolumn{3}{|c|}{ days 2 and 3} \\
\hline Anonymous & $\begin{array}{l}\text { Original } \\
\text { Portuguese }\end{array}$ & $\begin{array}{l}\text { Ate quatro pessoas enviaram-lhe propostas de } \\
\text { divisao de } 35 \mathrm{Mts} \text { em conta mKesh. Para cada } \\
\text { proposta/pessoa: se aceitar. ambos recebem os } \\
\text { valores da proposta. se nao aceitar. ninguem recebe } \\
\text { nada. }\end{array}$ & $\begin{array}{l}\text { A pessoa [1-4] propoe dar-lhe [up to } 35] \text { Mts e ficar } \\
\text { com o resto (de } 35 \mathrm{Mts}) \text {. Se quiser aceitar esta } \\
\text { proposta responda SIM. }\end{array}$ & $\begin{array}{l}\text { Pode ganhar com outra pessoa } 35 \mathrm{Mts} \text { em mKesh. Proponha } \mathrm{q} / \text { tos Mts de } 35 \text { devem ir p/pessoa 1: se ela } \\
\text { aceitar. ambos recebem prop/a. senao nada. Resp/a n/o de } 0-35 \mathrm{em} 24 \mathrm{~h} \text {. }\end{array}$ \\
\hline \multirow{3}{*}{$\begin{array}{c}\text { Non- } \\
\text { anonymous }\end{array}$} & $\begin{array}{l}\text { Original } \\
\text { Portuguese }\end{array}$ & $\begin{array}{l}\text { Ate quatro pessoas enviaram-lhe propostas de } \\
\text { divisao de } 35 \mathrm{Mts} \text { em conta mKesh. Para cada } \\
\text { proposta/pessoa: se aceitar. ambos recebem os } \\
\text { valores da proposta. se nao aceitar. ninguem recebe } \\
\text { nada. }\end{array}$ & $\begin{array}{l}\text { A pessoa [1-4] propoe dar-lhe [up to } 35] \text { Mts e ficar } \\
\text { com o resto (de } 35 \mathrm{Mts} \text { ). S/nome e [e.g., JOSE]. tem } \\
\text { [e.g., 30]. a [8a cl.]. e tem rend/os de [661- } \\
\text { 1320]Mts/mes. Se quiser aceitar esta proposta } \\
\text { responda SIM. }\end{array}$ & $\begin{array}{l}\text { Pode ganhar com outra pessoa } 35 \mathrm{Mts} \text { em mKesh. Proponha } \mathrm{q} / \text { tos Mts de } 35 \text { devem ir p/pessoa } 1 \text { : se ela } \\
\text { aceitar. ambos recebem prop/a. senao nada. S/nome e [e.g., JOSE]. tem [e.g., 30]. a [e.g., } 8 \text { a cl.]. e tem } \\
\text { rend/os de [e.g., 661-1320]Mts/mes. Resp/a n/o de 0-35 em } 24 \mathrm{~h} \text {. }\end{array}$ \\
\hline & & & Person [1-4] proposes to give you [up to 35] & \\
\hline & $\begin{array}{l}\text { English } \\
\text { translation }\end{array}$ & $\begin{array}{l}\text { Up to four different people sent you proposals to } \\
\text { divide } 35 \text { Meticais in your mKesh account. For each } \\
\text { proposal/person: if you accept, both you and that } \\
\text { person receive the values in the proposal; if you do } \\
\text { not accept, nobody earns any money. }\end{array}$ & $\begin{array}{l}\text { Meticais and keep the remainder (out of } 35 \\
\text { Meticais). His/her name is [first name of recipient in } \\
\text { capital letters]. He/she is [age] years old, has [level } \\
\text { of education], and has [income band in } \\
\text { Meticais]/month in income. If you want to accept } \\
\text { this proposal, respond YES. [These are up to } 4 \\
\text { messages, one for each person.] }\end{array}$ & $\begin{array}{l}\text { You can earn } 35 \text { Meticais in mKesh together with another person. Propose how many Meticais out of } 35 \\
\text { should de given to person [1-4]: if he/she accepts, you both earn the amounts you propose; if he/she does } \\
\text { not accept, nobody earns any money. He/she is [age] years old, has [level of education], and has [income } \\
\text { band in Meticais]/month in income. Respond with the value between } 0 \text { and } 35 \text { Meticais in the next } 24 \\
\text { hours. [These are } 4 \text { messages, one for each person.] }\end{array}$ \\
\hline & & \multicolumn{3}{|c|}{ day 4} \\
\hline Anonymous & $\begin{array}{l}\text { Original } \\
\text { Portuguese }\end{array}$ & $\begin{array}{l}\text { Ate quatro pessoas enviaram-lhe propostas de } \\
\text { divisao de } 35 \mathrm{Mts} \text { em conta mKesh. Para cada } \\
\text { proposta/pessoa: se aceitar. ambos recebem os } \\
\text { valores da proposta. se nao aceitar. ninguem recebe } \\
\text { nada. }\end{array}$ & $\begin{array}{l}\text { A pessoa [1-4] propoe dar-lhe [up to } 35] \text { Mts e ficar } \\
\text { com o resto (de } 35 \mathrm{Mts}) \text {. Se quiser aceitar esta } \\
\text { proposta responda SIM. }\end{array}$ & \\
\hline $\begin{array}{c}\text { Non- } \\
\text { anonymous }\end{array}$ & $\begin{array}{l}\text { Original } \\
\text { Portuguese }\end{array}$ & $\begin{array}{l}\text { Ate quatro pessoas enviaram-lhe propostas de } \\
\text { divisao de } 35 \mathrm{Mts} \text { em conta mKesh. Para cada } \\
\text { proposta/pessoa: se aceitar. ambos recebem os } \\
\text { valores da proposta. se nao aceitar. ninguem recebe } \\
\text { nada. }\end{array}$ & $\begin{array}{l}\text { A pessoa [1-4] propoe dar-lhe [up to } 35] \text { Mts e ficar } \\
\text { com o resto (de } 35 \mathrm{Mts} \text { ). S/nome e [e.g., JOSE]. tem } \\
\text { [e.g., 30]. a [8a cl.]. e tem rend/os de [661- } \\
1320] \mathrm{Mts} / \mathrm{mes} \text {. Se quiser aceitar esta proposta } \\
\text { responda SIM. }\end{array}$ & \\
\hline
\end{tabular}


Pode dar possibilidade de outras 4 pessoas ganhar

Pode ganhar 35Mts na sua conta mKesh. Para isso

Original Pode ganhar 35Mts na sua conta mKesh. Para isso
deve responder a esta mensagem com a palavra SIM

Portuguese $\begin{aligned} & \text { deve responder a estan } 24 \mathrm{~h} \text {. } \\ & \text { nas proximas }\end{aligned}$

Original Pode ganhar 35Mts na sua conta mKesh. Para isso

Original deve responder a esta mensagem com a palavra SIM

Portuguese nas proximas 24h.

Non-

anonymous

English You can earn 35 Meticais in your mKesh account.

English
translation message with the word YES in the next 24 hours.

35Mts cada uma. Para isso deve responder a cada Quer dar a ganhar 35Mts a pessoa [1-4]? Responda uma das seguintes mensagens com a palavra SIM nas SIM se quiser. proximas $24 \mathrm{~h}$

Pode dar possibilidade de outras 4 pessoas ganhar Quer dar a ganhar $35 \mathrm{Mts}$ a pessoa [1-4]? S/nome e 35Mts cada uma. Para isso deve responder a cada [e.g., JOSE]. tem [e.g., 30]. a [e.g., 8a cl.]. e tem

uma das seguintes mensagens com a palavra SIM nas rend/os de [e.g., 661-1320]Mts/mes. Responda SIM

Ate quatro pessoas enviaram-lhe $35 \mathrm{Mts}$ (cada uma) Recebeu 35Mts em mKesh da pessoa [1-4]. Deste

Original Ate quatro pessoas envia $35 \mathrm{Mts}$ (cada

Portuguese delas de volta. valor pode dar de volta ate $35 \mathrm{Mts}$. Resp/a valor que quer dar p/este n/o em $24 \mathrm{~h}$. A dif/a p/os 35 caira na $\mathrm{s} /$ conta mKesh.

Recebeu 35Mts em mKesh da pessoa [1-4]. S/nome

Original Ate quatro pessoas enviaram-lhe $35 \mathrm{Mts}$ (cada uma) e [e.g., JOSE]. tem [e.g., 30]. a [8a cl.]. e tem rend/o

Portuguese para a sua conta mKesh. Pode recompensar cada uma de [661-1320]Mts/mes. Deste valor pode dar de delas de volta. volta ate $35 \mathrm{Mts}$. Resp/a valor que quer dar $\mathrm{p} /$ este em 24h. A dif/a p/os 35 caira na s/ conta mKesh. You have received 35 Meticais from person [1-4] His/her name is [first name of recipient in capital

letters]. He/she is [age] years old, has [level of
log

Nonanonymous

English Up to four different people sent you 35 Meticais in your mKesh account. You can compensate each one translation $\begin{aligned} & \text { your mKesh account. } \\ & \text { of them back for that. }\end{aligned}$ education], and has [income band in Meticais]/month You can give the opportunity to 4 other people of in income. From this value you can give back up to winning 35 Meticais each. For that purpose, you 35 Meticais to person [1-4]. Respond with the value need to respond to each one of the following you want to give to this phone number in the next 24 messages with the word YES in the next 24 hours. hours. The difference to the 35 Meticais will be in one for each person.] proximas $24 \mathrm{~h}$

You can give the opportunity to 4 other people of winning 35 Meticais each. For that purpose, you need to respond to each one of the following messages with the word YES in the next 24 hours.

Pode dar possibilidade de outras 4 pessoas ganhar

35Mts cada uma. Para isso deve responder a cada uma das seguinte

Pode dar possibilidade de outras 4 pessoas ganhar $35 \mathrm{Mts}$ cada uma. Para isso deve responder a cada uma das segui proximas 24 se quiser.

Do you want to give person [1-4] the opportunity to earn 35 Meticais? His/her name is [first name of recipient in capital letters]. He/she is [age] years old, has [level of education], and has [income band in Meticais $]$ /month in income. Respond YES if you want. [These are 4 messages, one for each person.]

Quer dar a ganhar 35Mts a pessoa [1-4]? Responda SIM se quiser.

Quer dar a ganhar $35 \mathrm{Mts}$ a pessoa [1-4]? S/nome [e.g., JOSE] tem [e.g., 30]. a [e.g., 8a cl.]. e tem rend/os de [e.g., 661-1320]Mts/mes. Responda SIM se quiser.

Do you want to give person [1-4] the opportunity to earn 35 Meticais? His/her name is [first name of recipient in capital letters]. He/she is [age] years old, has [level of education], and has [income band in Meticais $]$ /month in income. Respond YES if you want. [These are 4 messages, one for each person.] Original Ate quatro pessoas enviaram-lhe 35 Mts (cada uma) Recebeu 35Mts em mKesh da pessoa [1-4]. Deste

Original valor pode dar de volta ate $35 \mathrm{Mts}$. Resp/a valor que quer dar p/este n/o em 24h. A dif/a p/os 35 caira na s/ conta mKesh.

Recebeu 35Mts em mKesh da pessoa [1-4]. S/nome

Ate quatro pessoas enviaram-lhe $35 \mathrm{Mts}$ (cada uma) e [e.g., JOSE]. tem [e.g., 30]. a [8a cl.]. e tem rend/os

Original para a sua conta mKesh. Pode recompensar cada uma de [661-1320]Mts/mes. Deste valor pode dar de delas de volta. $\quad$ volta ate $35 \mathrm{Mts}$. Resp/a valor que quer dar $\mathrm{p} / \mathrm{este} \mathrm{n} / \mathrm{o}$ volta ate $35 \mathrm{Mts}$. Resp/a valor que quer dar p/este
em $24 \mathrm{~h}$. A dif/a p/os 35 caira na s/ conta mKesh. You have received 35 Meticais from person [1-4] His/her name is [first name of recipient in capital letters]. He/she is [age] years old, has [level of education you want to give to this phone number in the next 24 hours. The difference to the 35 Meticais will be in your mKesh account. [These are up to 4 messages, 